\title{
Middle Triassic bivalve traces from central Europe (Muschelkalk, Anisian): overlooked burrows of a common ichnofabric
}

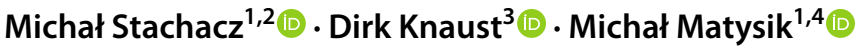

Received: 13 December 2020 / Accepted: 18 September 2021 / Published online: 9 November 2021

(c) The Author(s) 2021

\begin{abstract}
The ichnotaxonomy, producers and ethology of the bivalve trace fossil Oravaichnium Plička and Uhrová, 1990 are revised, and the mode of formation is discussed. The ichnogenus is compared with other mollusc trace fossils such as Protovirgularia, Lockeia and Ptychoplasma, as well as the common, cosmopolitan trace fossils Planolites and Palaeophycus, which are morphologically similar to Oravaichnium. A lectotype of Oravaichnium hrabei Plička and Uhrová, 1990 is defined and illustrated. Oravaichnium carinatum isp. nov. from the Middle Triassic of Poland and Germany is described and interpreted as a bivalve burrow. It differs from the relatively rare $O$. hrabei by a carinate rather than subquadrate cross section. However, $O$. carinatum isp. nov. shows a great variation of morphology and transitional forms with $O$. hrabei are common. Similarly, transitional forms of Oravaichnium with other bivalve ichnogenera, especially Protovirgularia, also occur. The studied Triassic ichnoassemblage clearly indicates that bivalve burrows are much more common than previously believed and are represented by repichnia, fodinichnia and cubichnia. The occurrence of similar ichnofabrics containing Oravaichnium in other Triassic succession of the Germanic and Tethys basins and elsewhere suggests a much wider distribution than hitherto known. It is evident that bivalves, most likely nuculids, participated greatly in bioturbation, and the Middle Triassic infaunalisation is one of the most important steps in Phanerozoic evolution of ichnocoenoses.
\end{abstract}

Keywords Trace fossil $\cdot$ Bivalve burrow $\cdot$ Oravaichnium $\cdot$ Bioturbation $\cdot$ Muschelkalk $\cdot$ Ichnotaxonomy

\section{Introduction}

Trace fossils attributed to the burrowing activity of bivalves are common in the fossil record from the early Cambrian (e.g., Orłowski and Żylińska 2002) to the Quaternary

Handling editor: Mike Reich.

Michał Stachacz

pascichnia@gmail.com

Dirk Knaust

dkna@equinor.com

Michał Matysik

michal.matysik@uj.edu.pl

1 Institute of Geological Sciences, Jagiellonian University, Gronostajowa 3a, 30-387 Kraków, Poland

2 Present Address: Korzeniowskiego 27e/5, 30-214 Kraków, Poland

3 Equinor ASA, 4035 Stavanger, Norway

4 Michał Matysik Geoconsulting, Malachitowa 5/3, 30-798 Kraków, Poland
(Schäfer 1962) and include ichnogenera such as Protovirgularia M'Coy, 1850; Lophoctenium Richter, 1850; Lockeia James, 1879; Ptychoplasma Fenton and Fenton, 1937; Siphonichnus Stanistreet et al., 1980; Oravaichnium Plička and Uhrová, 1990; Solemyatuba Seilacher, 1990; Scalichnus Hanken et al., 2001; Hillichnus Bromley et al., 2003; Saronichnus Pervesler and Zuschin, 2004; and Oblongichnus Bel Haouz et al., 2020. The Middle Triassic (Anisian) epicontinental carbonates (Muschelkalk) of Europe (Germanic Basin) are famous for their fossil content, which has been collected and investigated for centuries. Aside from skeletal fossils, the Muschelkalk contains the richest trace-fossil assemblage of any Triassic succession worldwide (Knaust 1998, 2007; Chrząstek 2013; Stachacz and Matysik 2020), including abundant bivalve traces.

The Muschelkalk succession provides a great natural laboratory for ichnological research and its trace-fossil associations have been recognised for centuries (see overview in Knaust 2007; Knaust and Hagdorn 2020). Already in 1761, Schütte mentioned 'Beinbruch, Bruchstein und Beinstein' (German expressions for bone fragments made 
of stone), apparently referring to the commonly occurring burrows in the shape of vertebrate ribs, which now can mostly be assigned to the ichnogenera Oravaichnium and Planolites. The same features were described by Batsch (1802) as 'Wurm-Kalkstein' (worm limestone). Mayer (1954) interpreted stalk-like bodies from the Upper Muschelkalk of SW Germany as the casts of decayed worms and named them Triadonereis and their traces Triadonereites. Now, these structures are identified as trace fossils, but despite their abundance, particularly in the Lower Muschelkalk, their scientific determination remains difficult due to a partly unclear and unresolved ichnotaxonomic situation.

In one of his ichnological papers about the Muschelkalk, the celebrated German palaeontologist Arno Hermann Müller dealt with these trace fossils and compared them with Teichichnus rectus Seilacher, 1955, based on their overall wall-shaped morphology (Müller 1959). However, the burrows from the Muschelkalk lack the internal spreite that is diagnostic of Teichichnus, and therefore Müller proposed the ichnogenus name 'Teichichnites', with reference to its morphological similarity to Teichichnus. Nevertheless, 'Teichichnites' as name only exists on the label attached to the original specimen but was never formally introduced and therefore remains a nomen nudum.

Many intervals of the Lower Muschelkalk consist of deposits that are strongly bioturbated supposedly by bivalves, which form a characteristic ichnofabric known in the Tethys area as 'vermicular limestone' (e.g., in the nearby Tatra Mountains of the Alpine domain, Jaglarz and Uchman 2010). The German term 'Muschelkalk' just means 'limestone with mussels' or 'shelly limestone' and is derived from the mass occurrence of bivalve and brachiopod shells, usually forming coquinas. Although the bivalves rarely occur in situ within their burrows, their great accumulation in strongly bioturbated beds leaves little doubt about their role in producing these burrows. This can also be supported by modern analogues and experiments with burrowing bivalves. Even if rarely recognised outside the Germanic Basin, these burrows seem to be much more common than hitherto known. For instance, similar straight burrows without the typical chevron-like pattern were often assigned to Planolites (e.g., Plička and Uhrová 1990) or Palaeophycus (e.g. Bel Haouz et al. 2020).

The aim of this contribution is to document these common burrows and to provide descriptive and quantitative data for showing their broad morphological and dimensional variation. Comparison with similar trace fossils in other regions and strata is intended to aid recognition of these characteristic trace fossils. Given these data and a reinvestigation of the type material, the taxonomy of the ichnogenus Oravaichnium is revised, a lectotype for its type ichnospecies $O$. hrabei selected, and its diagnosis revised.

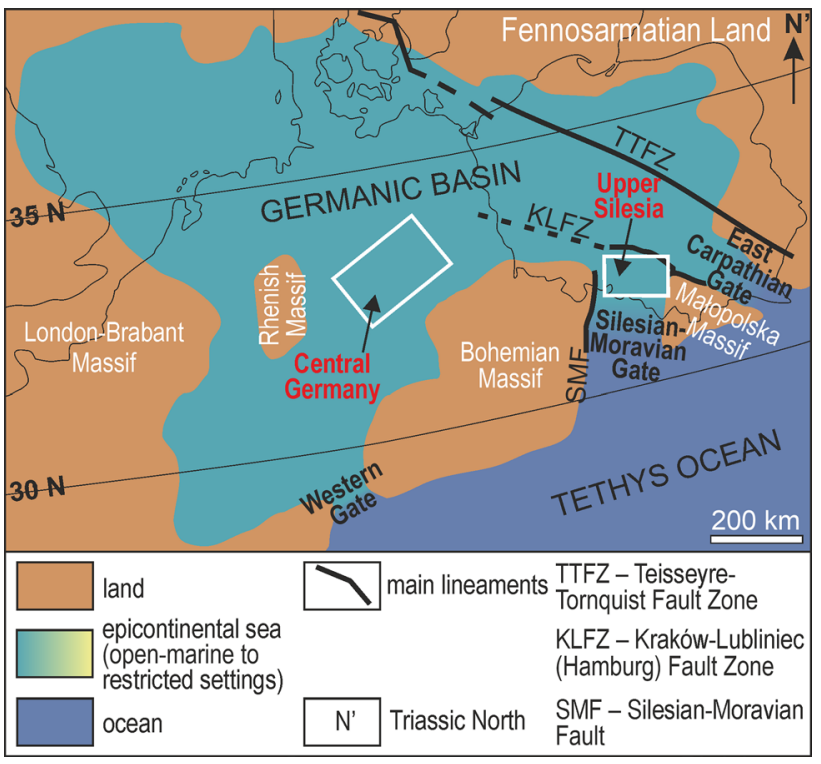

Fig. 1 Palaeogeographic position of the Upper Silesia and central Germany study regions (white frames). Modified from Szulc (2000)

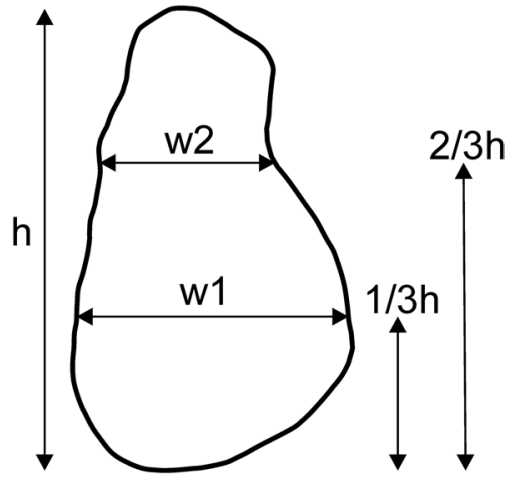

Fig. 2 Method of measuring of selected burrow cross sections at $1 / 3$ and $2 / 3$ of their height

\section{Materials and methods}

Hundreds of specimens of trace fossils attributed to the activity of burrowing bivalves were investigated from the Muschelkalk of Poland, Germany and France. The Polish material is represented by specimens from several quarries in the Lower Muschelkalk in the Kraków-Silesia Upland and Opole areas (Fig. 1), mostly from the Gogolin Beds and the Terebratula Beds. Sixty individual burrow fragments, including selected type material of Oravaichnium carinatum isp. nov., were separated from the host rock (mostly of the Lower Gogolin Beds), sliced serially and measured in detail. The width of these specimens was measured in vertical cuts, at $1 / 3$ and $2 / 3$ of the burrow 
height (Fig. 2). Moreover, 422 specimens of Oravaichnium (353 from Poland and 69 from Germany) were separated from the host rock and investigated in vertical cuts and their width and height measured. All collected specimens from Poland are housed in the Institute of Geological Sciences, Jagiellonian University of Kraków, and labelled with the prefix INGUJ214P. In addition, a great number of these trace fossils were observed in the field. For regional comparison, the comprehensive material from Poland was compared with numerous uncatalogued specimens and field observations from the Muschelkalk in Thuringia, Germany, and several observations in France.

\section{Geological setting}

\section{Palaeogeography}

During the Middle Triassic, the tropical Germanic Basin was enclosed by several land massifs and had a marine connection with the Tethys Ocean in the South via three narrow, sub-meridional depressions, so-called gates (Fig. 1). This semi-enclosed basin configuration determined a characteristic distribution of depositional environments, with normalmarine settings prevailing near the gates and more restricted and/or clastic-influenced settings in central to marginal basin areas (Szulc 2000). It also led to pronounced facies diachrony between the gates and basin margins, reflecting progressive northward transgressions from the Tethys Ocean. The gates developed at the tips of the Tethyan rift system, opening and closing diachronously from east to west, following westward relocation of the Tethyan spreading centre (Szulc 2000).

The East Carpathian and Silesian-Moravian Gates were already open by the Olenekian and were the basin's only connections with the Tethys until the Pelsonian, when the Western Gate also became active. Subsequent crustal uplift in the Polish province resulted in the gradual closing of the two eastern gates, and a stratigraphic hiatus last almost throughout the Ladinian, whereas the Western Gate persisted until the middle Ladinian (Szulc 2000). As a consequence of these three factors (semi-enclosed basin character, facies diachrony, and temporal evolution of the gates), marine conditions appeared in south-eastern Poland three depositional sequences earlier than in Western Europe, and conversely, the Upper Muschelkalk is much thicker and open-marine in Western Europe, where it formed three conodont zones and six ceratite zones longer than in Poland (Szulc 2000).

The Upper Silesia study region lay just at the northern outlet of the Silesian-Moravian Gate and saw the most open-marine conditions of all the regions of the Germanic Basin. In contrast, Thuringia and surrounding Muschelkalk areas in Germany were located centrally, relatively close to the Western Gate but far from the two eastern gates, which resulted in an increase of siliciclastic influx and more restricted environments overall. Despite the marked distance between the two study areas (ca. $700 \mathrm{~km}$ ), they display a consistent depositional history of third-order relative sealevel changes.

\section{Stratigraphy of the Muschelkalk in Upper Silesia and Thuringia}

The marine carbonates of the Germanic Basin represent six third-order transgressive-regressive depositional sequences that are bounded by distinct subaerial exposure horizons (Szulc 2000; Fig. 3). The sequences are well correlated with the Alpine successions by means of magnetostratigraphy (Nawrocki and Szulc 2000) as well as conodont, ammonoid, crinoid, green algae, and conchostracan biostratigraphy (Assmann 1944; Zawidzka 1975; Hagdorn and Głuchowski
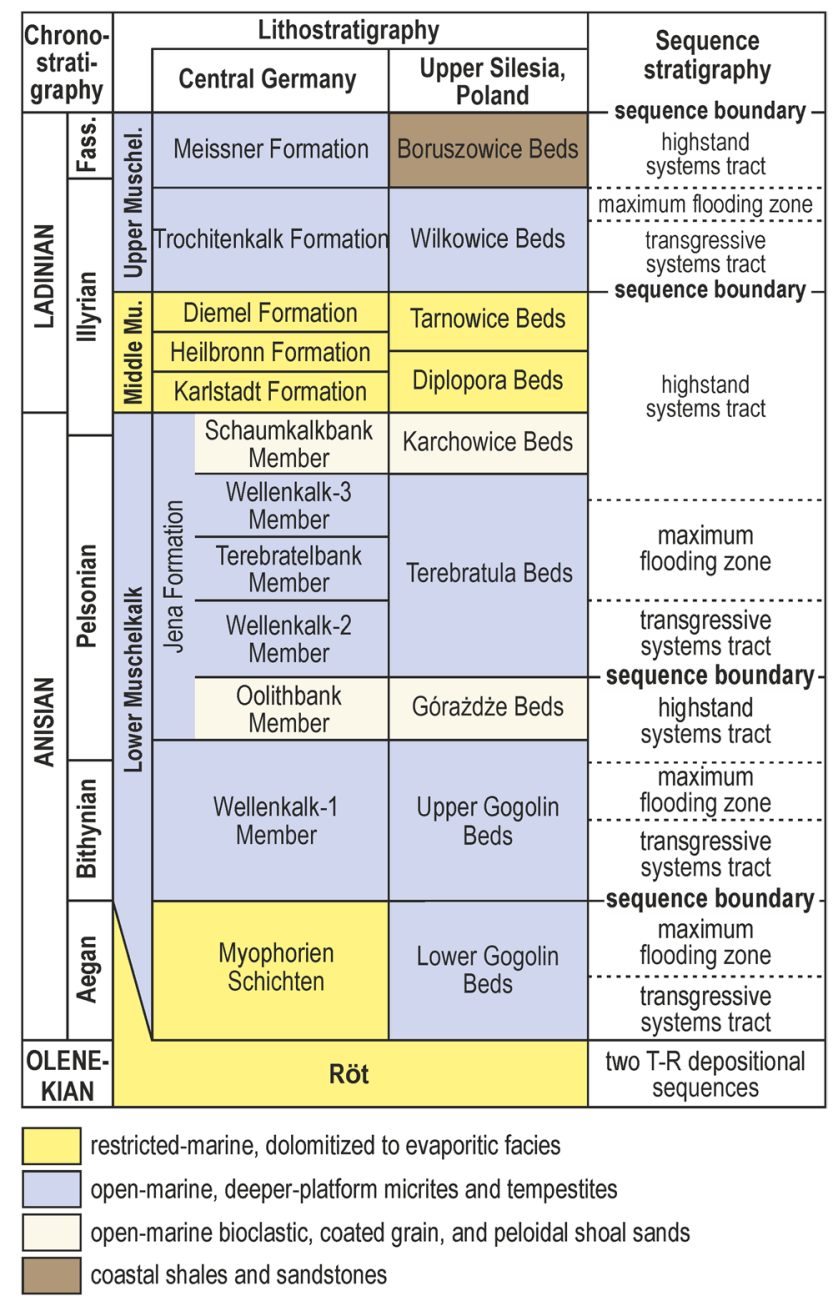

Fig. 3 Simplified correlation of the Röt and Muschelkalk between Upper Silesia and central Germany study areas, based on sequencestratigraphic units 
1993; Kotański 1994; Kaim and Niedźwiedzki 1999; Bachmann and Kozur 2004; Narkiewicz and Szulc 2004).

The first two sequences (Olenekian) are composed predominantly of lagoonal dolostones and coastal siliciclastics, with minor open-marine limestones in Upper Silesia and evaporites towards the basin centre and margins. These facies are collectively termed as Röt. The third sequence (Aegean) is entirely open-marine in Upper Silesia and dominated by deep-ramp micrites and bioclastic tempestites (Lower Gogolin Beds), which defines the onset of the Lower Muschelkalk. In Germany, deposition of restricted-marine Röt facies continued at that time. The fourth sequence (Bithynian) records a pronounced sea-level rise, as openmarine facies reached Western Europe for the first time. The transgressive phase is represented by deeper platform micrites and tempestites (Upper Gogolin Beds in Upper Silesia and Wellenkalk-1 Member in Germany), whereas the regressive phase is characterised by oncoid-peloid-ooid sand shoals (Górażdże Beds in Upper Silesia and Oolith Beds in Germany).

The fifth sequence (Pelsonian-Illyrian) formed during the maximum transgression of Tethys, leading to the accumulation of deeper platform micrites and tempestites across nearly the entire Germanic Basin (Terebratula Beds in Upper Silesia and Wellenkalk-2, Terebratula Beds, and Wellenkalk-3 members in Germany). These transgressive facies are overlain by a regressive suite of bioclastic, coated-grain, and peloidal shoal sands (Karchowice Beds in Upper Silesia and Schaumkalk Beds in Germany), which in Upper Silesia contain sponge-scleractinia patch reefs. A further relative sea-level drop led to a change from openmarine to restricted-marine sedimentation, with back-reef and lagoonal dolostones dominating in Upper Silesia (Diplopora and Tarnowice Beds) and evaporites and dolostones developing in Germany (Karlstadt, Heilbronn, and Diemel formations). These restricted-marine facies define the Middle Muschelkalk.

The last (sixth) sequence is represented by the Upper Muschelkalk and marks a return of open-marine carbonate sedimentation to the Germanic Basin. The strata commence with widespread transgressive facies of deeper platform micrites and tempestites (Wilkowice Beds in Upper Silesia and Trochitenkalk Formation in Germany). These facies persisted in Germany during the subsequent highstand (Meissner Formation), whereas the highstand in Upper Silesia is siliciclastic and formed in a remnant sea (Boruszowice Beds).

Details of the stratigraphy, sedimentology and environmental setting of the Upper Silesian Muschelkalk are discussed by numerous workers, particularly by Assmann (1944), Szulc (2000), Matysik (2010, 2014, 2016, 2019) and Matysik and Szulc (2019). Several aspects of the German Muschelkalk, such as stratigraphy, sedimentology, palaeontology, and geochemistry, were recently covered by the Deutsche Stratigraphische Kommission (2020, and references therein).

The studied bivalve trace fossils have been found mainly in open-marine strata, which are typically highly bioturbated and ichnotaxonomically diversified. These strata include the entire Lower Muschelkalk in the Kraków-Silesia Upland and the Lower and Upper Muschelkalk in Germany.

\section{Systematic ichnology}

Institutional abbreviations. INGUJ-Institute of Geological Sciences, Jagiellonian University, Kraków, Poland; MB.W.-Palaeontological Collection of the Museum of Natural History in Berlin; SMF-Palaeontological Collection of the Senckenberg Institute, Frankfurt am Main, Germany.

Ichnogenus Oravaichnium Plička and Uhrová, 1990

2020 Oblongichnus-Bel Haouz et al.: 4, figs. 4-8

Type ichnospecies. Oravaichnium hrabei Plička and Uhrová, 1990.

Diagnosis (revised after Uchman et al. 2011). Straight, winding or meandering unbranched burrow with subrect angular or carinate cross section, homogeneous fill, and smooth or faintly chevroned margin.

Remarks. Originally diagnosed as 'cylindrical trace', a revised diagnosis was provided by Uchman et al. (2011) to stress the 'box-like (non-carinate) cross section'. While this diagnosis remains appropriate for the type ichnospecies of Oravaichnium, this ichnogenus comprises a wide range of morphotypes. Based on the variability of Oravaichnium as analysed from the Muschelkalk, we revise the ichnogeneric diagnosis to include congeneric forms with a carinate cross section.

Oblongichnus solodukhoi Bel Haouz et al., 2020, the type ichnospecies of Oblongichnus Bel Haouz et al., 2020, is herein regarded as a junior subjective synonym of Oravaichnium hrabei (see below) and consequently Oblongichnus as junior synonym of Oravaichnium. Oravaichnium may grade into Protovirgularia by developing or preserving a faint chevron-like ornamentation, but differs from it by the characteristic cross section and an ornamentation that may occur on both, the ventral (lower) and dorsal (upper) burrow part. 

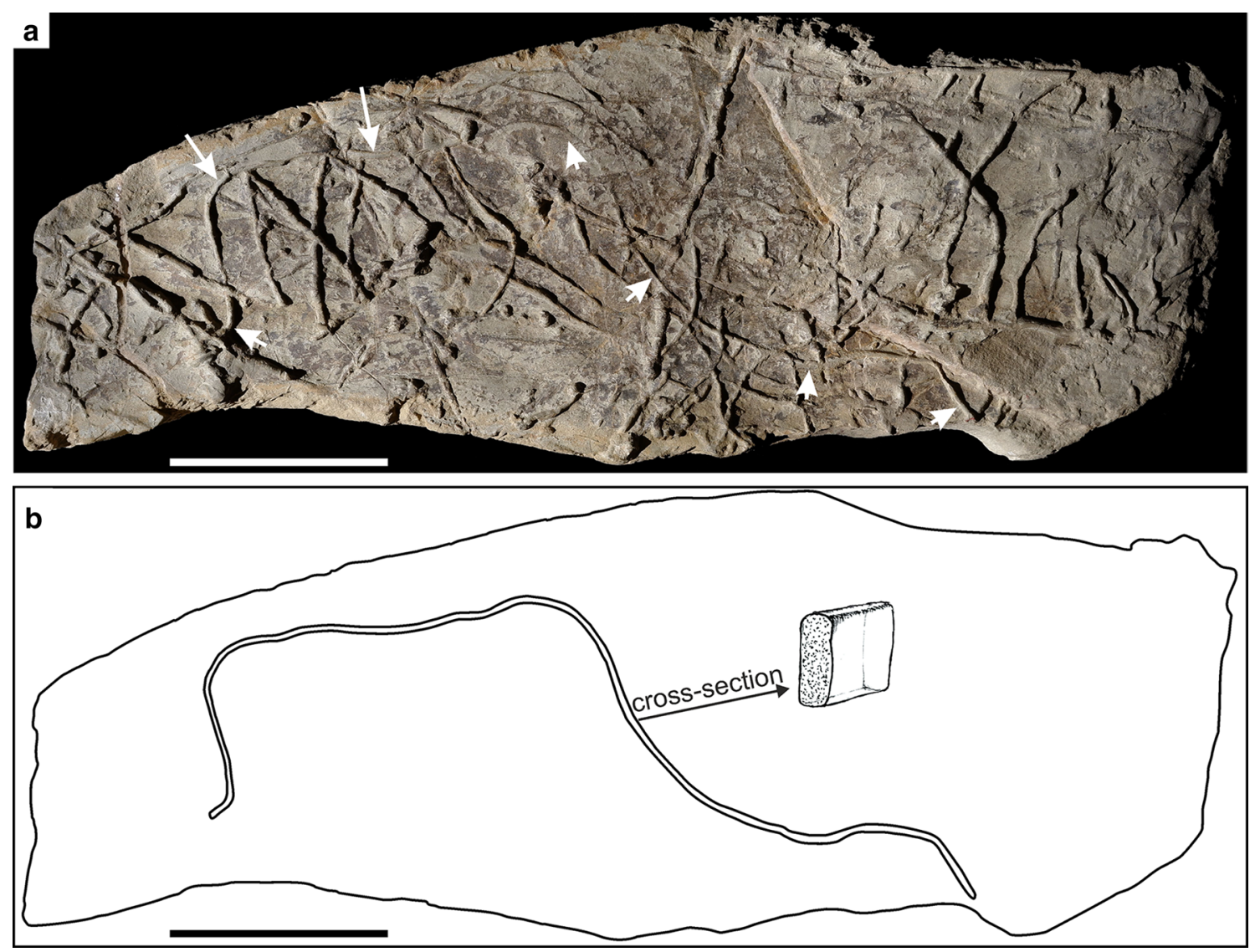

Fig. 4 Oravaichnium hrabei Plička and Uhrová, 1990, lectotype as herein defined (arrows) and paralectotypes (remaining specimens), preserved as hypichnial ridges on the lower bedding plane. Zlin Beds, Eocene, Oravska Lesna, flysch Carpathians, the Moravian Museum,
Moravec Depository, No Ge 26017. Scale bar $=10 \mathrm{~cm}$. a Photograph of the slab with the selected lectotype (arrowed). b Simplified line drawing of the slab showing the lectotype, drawings of cross section in the inset

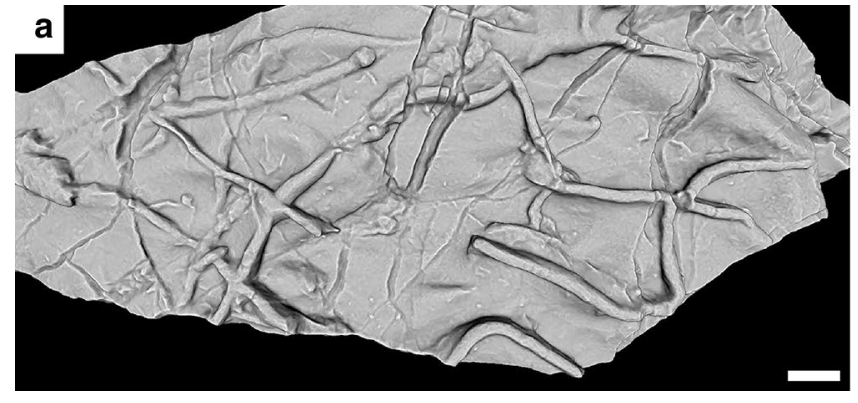

Fig. 5 Oravaichnium hrabei in 3-D scans with distinct, subquadrate shape. Middle Eocene Beloveza Formation, Zbludza, Magura Unit, Polish flysch Carpathians, 144P43, Nature Education Centre of the

\section{Oravaichnium hrabei Plička and Uhrová, 1990}

Figures 4, 5 and 6

Lectotype and paralectotypes. The original material of $O$. hrabei from the Eocene of Slovakia is housed in the Moravec Depository of the Brno Museum, Czech Republic, and consists of a large slab with numerous burrows (catalogue

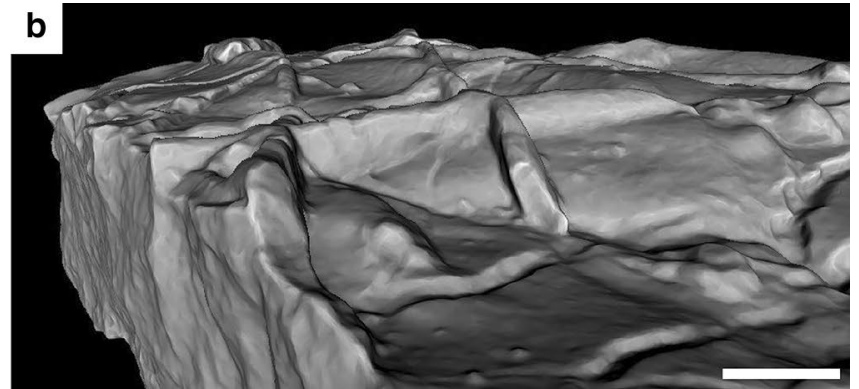

Jagiellonian University. Scale bars $=1 \mathrm{~cm}$. a Hypichnial view. b Hypichnial-oblique view showing cross section of the burrow

number Ge26017, not Ge2601 as mistakenly stated in Uchman et al. 2011). Plička and Uhrová (1990) as well as Uchman et al. (2011) figured that slab and collectively treated all burrows on it as 'holotype', instead of selecting a single specimen, which would be a requirement according to the rules of the International Code of Zoological Nomenclature (ICZN 1999). Consequently, the best preserved and 

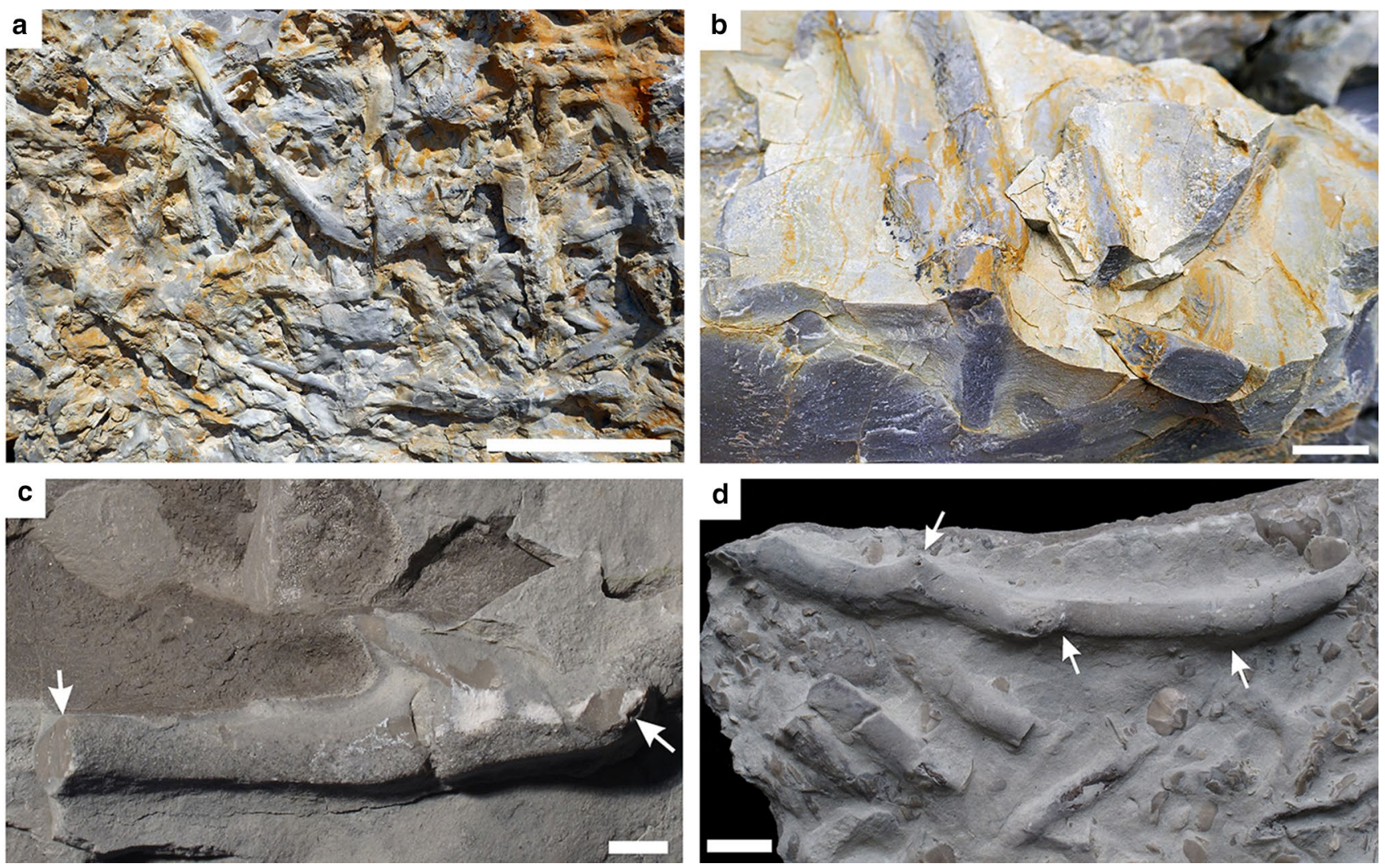

Fig. 6 Oravaichnium hrabei from the Middle Triassic. Scale bars $=10 \mathrm{~cm}$ (a) and $1 \mathrm{~cm}(\mathbf{b}-\mathbf{d})$. a Dense ichnofabric (lower bedding plane). Upper Muschelkalk (Ladinian), Vellechevreux-et-Courbenans, NE France. b Several specimens exhibiting their variable cross sections and inclination to bedding (lower bedding plane). Lower

developed burrow on that slab is herein defined as the lectotype of $O$. hrabei, all other specimens being paralectotypes (Fig. 4).

Other material. Two catalogued slabs from the Middle Triassic limestone (Muschelkalk) of Poland, which contain several specimens (INGUJ214P/SO6, Gr6), numerous specimens observed in the field, not only in Poland but also in Thuringia (Germany) and France.

Diagnosis (after Uchman et al. 2011). In hypichnial view, a smooth, continuous ridge, subquadrate in cross section, irregularly meandering, winding or looping.

Description. The herein designated lectotype (Fig. 4, arrows) is preserved as hypichnial ridge at the base of a fine-grained sandstone slab. It is ca. $490 \mathrm{~mm}$ long, has an almost constant width of $2-3 \mathrm{~mm}$ and a height of ca. $3 \mathrm{~mm}$. The burrow is irregularly winding (but not crossing over), with a relatively long straight portion, and curves rarely reaching an angle of $90^{\circ}$. Its cross section is subrectangular, non-carinate,
Muschelkalk (mu2, Anisian), Quarry Plaue, Thuringia. c Two specimens showing a subrectangular cross section (arrows). Upper Gogolin Beds, Górażdże. d Specimen with short protuberances (arrows). Upper Gogolin Beds, Górażdże

with slightly rounded edges. Other burrows of that slab are almost straight, slightly curved to irregularly meandering, 60-220 mm long, 2-3 mm wide and ca. $3 \mathrm{~mm}$ high. Faint striae are present on the side walls (margins) of the burrows and run perpendicular to the burrow axes. These striae are best pronounced in the bends of the burrows.

The Middle Triassic specimens are preserved as exichnial and hypichnial full relief (Fig. 6). The burrows have a straight or arcuate, winding, or irregularly meandering course, and are horizontal to oblique, rarely vertical to the bedding. The continuous ridges or endichnial burrows have a subangular cross section, which is commonly slightly rounded. In rare cases, ridges are composed of continuous portions with slightly different course, resembling short probes of the burrows (Fig. 6d). The ridges are 4-11 mm (commonly 4-5 mm) wide, generally smooth, and their fill is micritic similar to the host rock.

Remarks. Oravaichnium hrabei from the Polish, German, and French Muschelkalk comprises exichnial and full-relief hypichnial burrows, which were formed post-deposition 
Table 1 Measurements of the paratypes at 1/3 and 2/3 of height, and their relations

\begin{tabular}{|c|c|c|c|c|c|c|c|c|c|c|c|c|}
\hline \multirow{2}{*}{$\begin{array}{l}\text { Sample no } \\
\text { Mil } 1\end{array}$} & \multirow{2}{*}{$\begin{array}{l}\text { Height }[\mathrm{mm}] \\
7-9\end{array}$} & \multicolumn{9}{|c|}{$\begin{array}{l}\text { Wide variations [mm], w1 was measured at } 1 / 3 \text { of height, w } 2 \text { was } \\
\text { measured at } 2 / 3 \text { of height of the burrow }\end{array}$} & \multirow{2}{*}{$\begin{array}{l}\text { Relations of } \\
\text { measured width } \\
\text { w2: w1 }\end{array}$} & \multirow{2}{*}{$\begin{array}{l}\text { Average w2: w1 } \\
0.78\end{array}$} \\
\hline & & w2 & 3.4 & 3.5 & 3.1 & 3.3 & 3.9 & 3.3 & 3.2 & 2.7 & & \\
\hline & & w1 & 4.5 & 4.1 & 3.8 & 3.8 & 4.5 & 4.1 & 4.4 & 3.9 & & \\
\hline \multirow[t]{2}{*}{ Mil 2} & $8-11$ & w2 & 3.5 & 3.4 & 3.9 & 3.2 & 3.6 & 3.5 & 3.5 & 3.8 & $0.72-1.05$ & 0.88 \\
\hline & & w1 & 4.6 & 4.7 & 3.7 & 4.1 & 4.5 & 4.0 & 4.6 & 4.8 & & \\
\hline \multirow[t]{2}{*}{ Mil 3} & $7-9$ & w2 & 5.5 & 4.8 & 4.6 & 2.8 & 3.0 & 2.9 & & & $0.65-1.02$ & 0.83 \\
\hline & & w1 & 5.4 & 5.2 & 5.0 & 3.9 & 4.6 & 4.2 & & & & \\
\hline \multirow[t]{2}{*}{ Mil 4} & $6-10$ & w2 & 4.9 & 4.7 & 4.7 & 4.9 & & & & & $0.82-0.98$ & 0.90 \\
\hline & & w1 & 5.6 & 5.7 & 5.0 & 5.0 & & & & & & \\
\hline \multirow[t]{2}{*}{ Mil 5} & 7 & w2 & 3.8 & 2.5 & 3.1 & 4.5 & & & & & $0.69-1.18$ & 0.93 \\
\hline & & w1 & 4.4 & 3.6 & 4.1 & 3.8 deformed & & & & & & \\
\hline \multirow[t]{2}{*}{ Mil 6} & $9-11$ & w2 & 4.6 & 4.2 & 4.0 & 3.6 & & & & & $0.68-0.84$ & 0.76 \\
\hline & & w1 & 6.0 & 5.0 & 5.6 & 5.3 & & & & & & \\
\hline \multirow[t]{2}{*}{ Mil 7} & $11-14$ & w2 & 5.4 & 4.7 & 4.3 & 4.6 & & & & & $0.77-0.94$ & 0.85 \\
\hline & & w1 & 5.8 & 5.0 & 5.6 & 5.2 & & & & & & \\
\hline \multirow[t]{2}{*}{ Mil 8} & $7-10$ & w2 & 4.0 & 4.1 & 4.1 & 4.4 & & & & & $0.84-0.92$ & 0.88 \\
\hline & & w1 & 4.4 & 4.6 & 4.9 & 4.8 & & & & & & \\
\hline \multirow[t]{2}{*}{ Zyg 1a } & $7.5-9.3$ & w2 & 3.2 & 3.3 & 3.5 & & & & & & $0.65-0.82$ & 0.73 \\
\hline & & w1 & 4.9 & 4.0 & 4.8 & & & & & & & \\
\hline \multirow[t]{2}{*}{ Zyg 1b } & $9.6-11,8$ & w2 & 4.3 & 4.6 & & & & & & & $0.84-0.92$ & 0.88 \\
\hline & & w1 & 5.1 & 5.0 & & & & & & & & \\
\hline All samples average & & & & & & & & & & & & 0.84 \\
\hline
\end{tabular}

(Stachacz and Matysik 2020). It is relatively rare in the Lower Muschelkalk of Poland, compared with the abundant $O$. carinatum isp. nov. Nevertheless, transitional forms of these two ichnospecies occur (Table 1). Specimens composed of probe-like portions with diverging courses originated from a stepwise movement of the producer, a supposed bivalve. $O$. hrabei from the Triassic is distinctly larger than specimens originally described from the Eocene flysch (e.g., Plička and Uhrová 1990; Uchman et al. 2011).

$O$. hrabei was originally described from the Neogene of the Carpathians, where it occurs in turbiditic beds and is interpreted as predepositional trace formed in a deep marine environment (Uchman et al. 2011). Although, at first it was assumed that '... this trace fossil is very rare and has so far been found only in the Eocene flysch deposits of the Carpathians' (Uchman et al. 2011), material from the Muschelkalk indicates its widespread distribution once this common ichnotaxon is properly recognised.

Subquadrate in cross section, partly chevroned specimens of $O$. hrabei resemble arthrophycids, i.e., Arthrophycus linearis and different ichnospecies of Phycodes, both attributed to polychaetes worms (cf. Seilacher 2000: figs. 2, 14). Especially, Arthrophycus brongniartii formed by arthropods (Rindsberg and Martin 2003) shows cross section and sculpture similar to O. hrabei. Nevertheless,
A. brongniartii is a burrow with complex morphology (cf. Rindsberg and Martin 2003: fig. 3), while O. hrabei is smooth, or faintly chevroned. The V-shaped chevron of $O$. hrabei corresponds to small fusiform (in lateral cross section) bivalve shells, and subquadrate cross section is most likely a result of burrowing with slightly parted valves. Moreover, numerous bivalves associated with $O$. hrabei support small bivalves as the producer of this trace fossil.

Oblongichnus solodukhoi Bel Haouz et al., 2020 is very similar to $O$. hrabei in having the same morphology, variable orientation, and course, but mainly differs from it by having ascribed a thick lining or burrow wall. Close inspection of the figured type specimens reveals that their 'lining' consists of the same sandy substrate as the burrow fill and most likely results from a lateral shift of the producer. This adjustment feature resembles an incipient spreite rather than the lining of the burrow wall. 'The thickness and kind of lining are variable' (Bel Haouz et al. 2020: 99), and the holotype only shows a narrow interspace between burrow fill and host rock, suggesting a very thin lining, if any. For these reasons, $O$. solodukhoi is regarded as a junior subjective synonym of O. hrabei.

Occurrence in the Muschelkalk. Lower Gogolin Beds in Żyglin and Płaza; Upper Gogolin Beds in Strzelce Opolskie, 

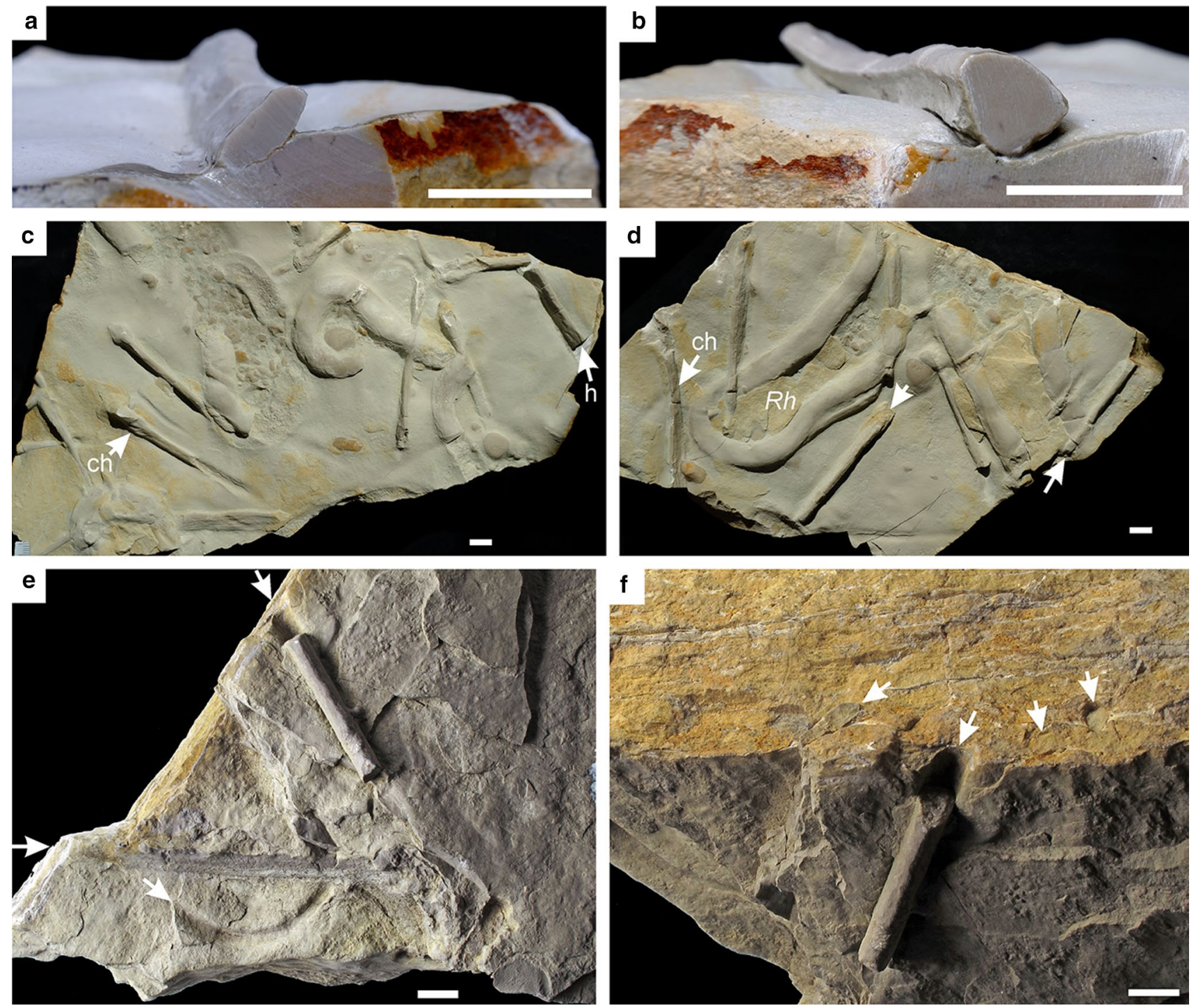

Fig. 7 Oravaichnium carinatum isp. nov. from the Middle Triassic of Poland and Germany. Scale bars $=1 \mathrm{~cm}$. a, b Both burrow ends to illustrate the variation in cross-sectional morphology and width/ height ratio (upper bedding plane). c, d Hypichnial view, h-holotype, ch-chevron, Rh-Rhizocorallium. a-c holotype, INGUJ214P/

Górażdże; Górażdże Beds in Górażdże; Terebratula Beds in Górażdże; Upper Muschelkalk in Thuringia, Germany, and France.

\section{Oravaichnium carinatum isp. nov.}

Figure 7, 8, 9, 10, 11 and 12

Etymology. From Latin carinatus, meaning 'keeled, having a keel-shaped ridge'.

Type locality. Żyglin near Tarnowskie Góry, active quarry, southern Poland.

Zyg2, d Zyg3, Lower Gogolin Beds, Żyglin. e, f Original slab (upper bedding plane) with several specimens (arrows) from Müller (1959), intended as the holotype for a new ichnogenus called 'Teichichnites' (nomen nudum). Phyletic Museum Jena, Germany. e, f Paralectotypes

Type stratum. Lower Gogolin Beds, Lower Muschelkalk.

Holotype. INGUJ214P/Zy2.

Paratypes. One catalogued slab containing eight specimens (INGUJ214P/Zy1) and 17 extracted burrows (INGUJ214P/ Mil1 to Mil17) from the Lower Gogolin Beds at Żyglin and Milowice, southern Poland.

Other material. Several slabs containing a few tens of specimens from the Lower Gogolin Beds at Żyglin, Moczydło, Milowice and Moczydło, the Upper Gogolin Beds at Górażdże, and the Lower Terebratula Beds at Strzelce 

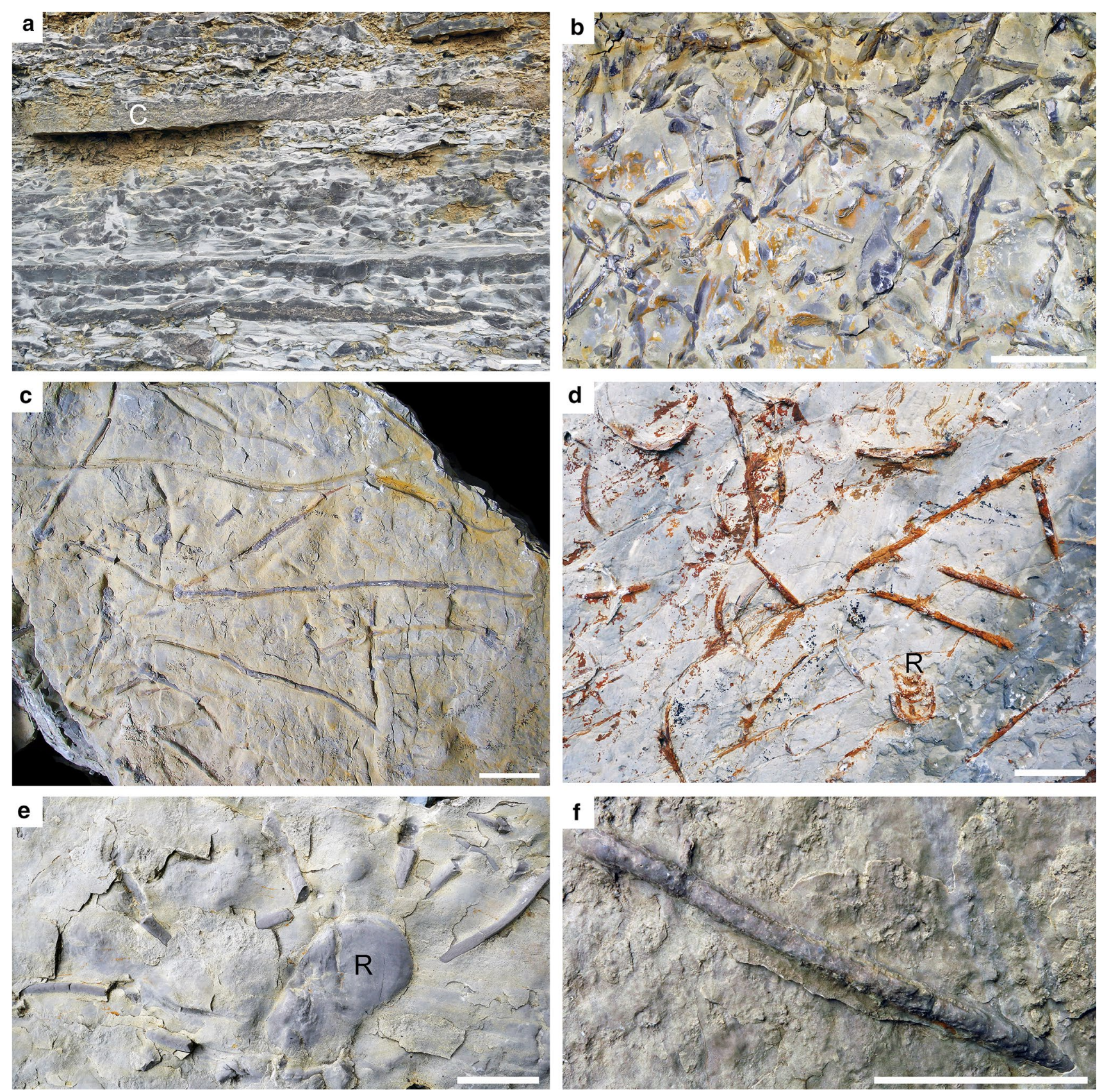

Fig. 8 Oravaichnium carinatum isp. nov. from the Lower Muschelkalk (Anisian) in outcrop (quarries in Thuringia, Germany). Scale bars $=5 \mathrm{~cm}$. a Vertical section of a marly limestone succession with a thin shell bed (coquina, $\mathrm{C}$ ) and an $O$. carinatum ichnofabric characterised by dark grey micritic burrows scattered in the light grey marly matrix. Plaue (mu2). b Lower bedding plane with numerous elongate, straight or slightly winding burrows, some of which are very shallowly arcuate (in vertical direction) or inclined to the bedding. Rittersdorf (mu3). c Upper bedding plane with long and winding, mic- ritic burrows, some of which have been removed from their marly substrate. Rittersdorf (mu1). d Upper bedding plane with straight and arcuate (laterally bent) burrows, which are associated with Rhizocorallium commune $(\mathrm{R})$ and subsequently stained with brown goethite. Plaue (mu3). e Upper bedding plane with $R$. commune surrounded by numerous $O$. carinatum at various inclinations to bedding. Plaue (mu3). f Lower bedding plane with shallow arcuate burrow with weakly developed chevron-like sediment pads (lower right) as in Protovirgularia. Haufeld (mu3)
Opolskie and Górażdże, Górażdże Beds in Strzelce Opolskie and Górażdże, southern Poland. Moreover, numerous specimens were observed in the field, both in Poland and in Germany. 


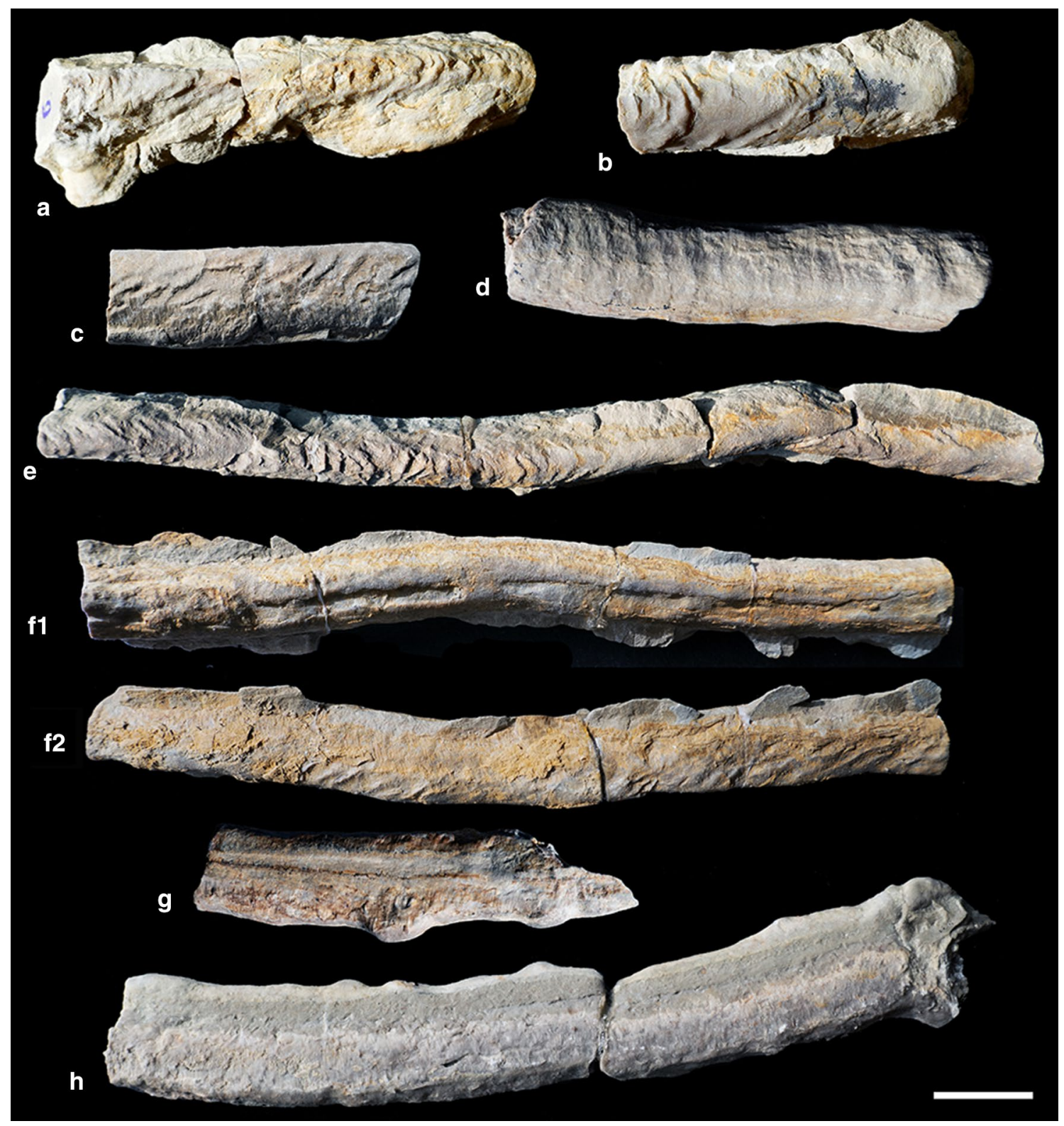

Fig. 9 Oravaichnium carinatum isp. nov. burrow casts (fragments, isolated from the matrix) showing characteristic features. Lower Muschelkalk (Anisian, mu3) of quarry Bad-Berka-Gutendorf (a-c) and quarry Plaue $(\mathbf{d}-\mathbf{h})$, Thuringia (Germany). Scale bar $=1 \mathrm{~cm}$. a Bottom view with dense sediment pads leaving chevron-like traces. b-d Lateral views with chevrons of varying intensity. e Bottom view

Diagnosis. Horizontal to oblique, straight or arcuate, walllike burrow with a downwardly or upwardly carinate, amygdaloid or pear-shaped cross section, essentially tapering in one or both directions, homogeneous fill, and smooth or faintly chevroned margin.

Description. Hypichnial, wedge-shaped or arcuate, convex ridges or endichnial walls with smooth or weakly ornamented margins, generally tapering towards one or both with dense sediment pads leaving chevron-like traces together with rather smooth intervals. f Top view (F1) with a longitudinal groove and bottom view (F2) with chevrons. g Lateral view with groove and basal extensions in an amygdaloid manner. $\mathbf{h}$ Lateral view of a smooth, wall-like burrow with irregular outline at its bottom and top

terminations. The burrows are filled with the same massive sediment (micrite) as the host rock, or with slightly darker sediment (Figs. 7, 8, 10). It can display an indistinct backfill with scattered, ellipsoidal faecal pellets of $0.2-0.6 \mathrm{~mm}$ (commonly $0.3 \mathrm{~mm}$ ) in diameter and $0.2-0.6 \mathrm{~mm}$ in length, which are filled with micrite lighter in colour than the burrow fill (Fig. 11a, c, f, g, i, j, o, s). The burrows have labile cross-sectional morphologies even through individual specimens (Fig. 11), which range from a relatively wide and oval 

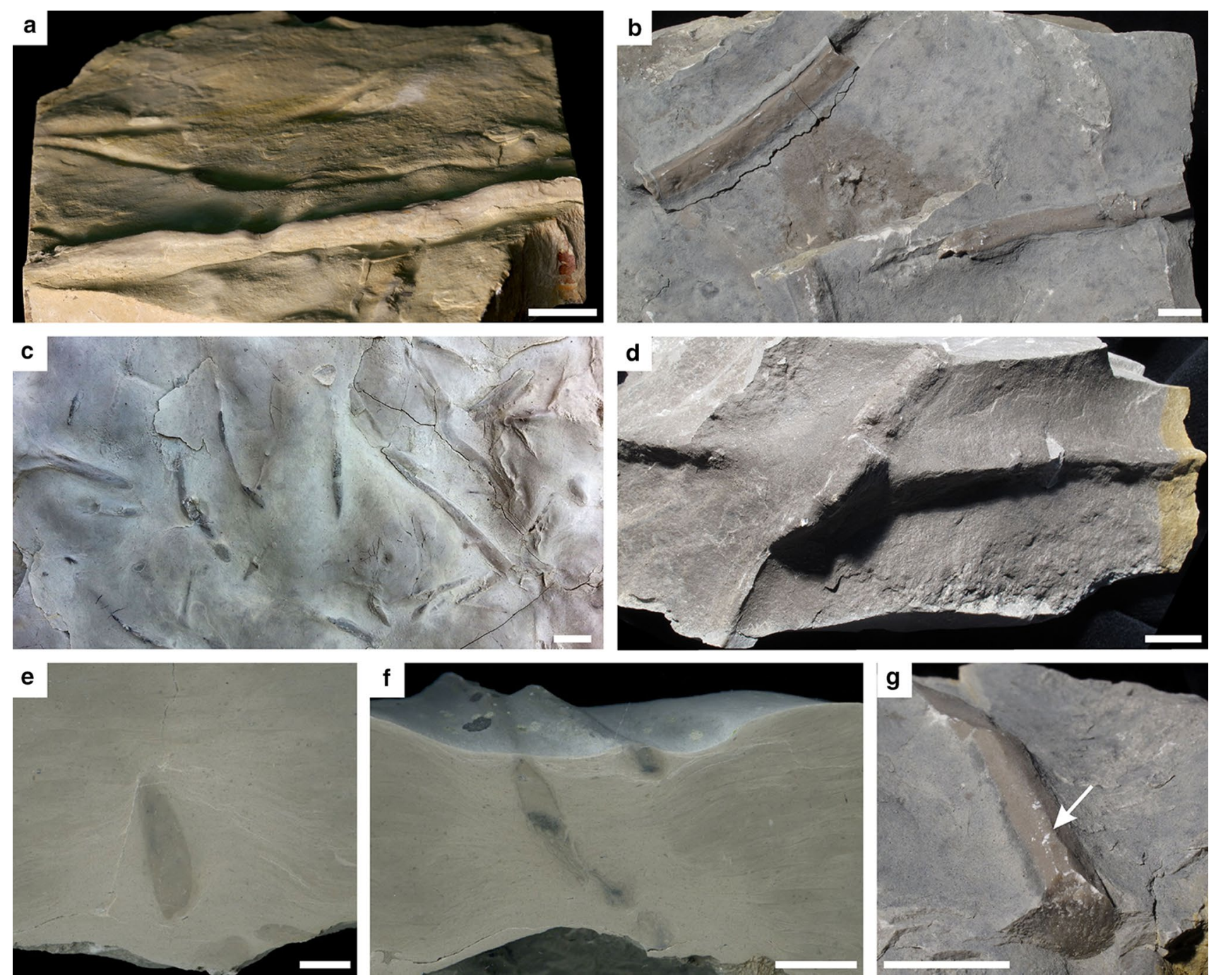

Fig. 10 Variation of Oravaichnium carinatum isp. nov. from the Polish Muschelkalk. Scale bars=1 cm. a Corrugated form, b-g Smooth form. a-c, f-g Upper Gogolin Beds, Strzelce Opolskie. d Górażdże Beds, Górażdże

shape, to pear or elongated amygdaloid shape, to slim burrows with a sharp keel and burrow terminations plunging into the bed in some cases. Most specimens thin upwards; fewer thin towards their base. Tapering upward and downward have both been observed within the same burrow (Figs. 11a, d, 12).

Burrow width, measured in the same cross sections at $1 / 3$ and $2 / 3$ of burrow height (Fig. 2, Table 1), is $3.8-6.0 \mathrm{~mm}$ (w1, Fig. 2) and 2.5-5.5 mm (w2), respectively; the w1/w2 ratio varies between 0.73 and 0.93 (average 0.84 , Table 1 ). The pear-shaped cross section is the most common morphological variant and appears in various combinations (Fig. 11), whereas some ridges are relatively high and form a vertical or oblique wall (Fig. 111, p). Most of the 422 measured burrows have a width/height ratio between 0.3 and 1.7 (Fig. 13). The ridges are generally smooth, rarely corrugated or irregularly serrated (Fig. 10a), although faint ornamentation formed by longitudinal narrow grooves or chevron-like patterns may occur (Figs. 7c, d, 9a-f, 14a-c).

Burrow fill is generally the same as the host rock, except for the specimens from the Terebratula Beds where it is commonly darker or composed of coarser material than the host sediment (Stachacz and Matysik 2020). Some burrows have the shell of the bivalves? Myoconcha bicostata or Pleuromya rugosa at their terminations, although their relationship to the burrow (e.g., accidental or producing it) remains questionable (Fig. 15). The ridges run parallel or obliquely to the bedding, in some cases having a rotation around their axis up to $90^{\circ}$. The original upper surface of the ridges may display a slight furrow (Fig. 9f), which may be a secondary feature due to reburrowing. The maximum width of the ridges is 2-29 mm (3-7 mm wide in more than $90 \%$ of 422 measured specimens) and their height is $2-20 \mathrm{~mm} \mathrm{(3-12} \mathrm{mm}$ in ca. $90 \%$ of 422 measured specimens), with a width/height ratio 

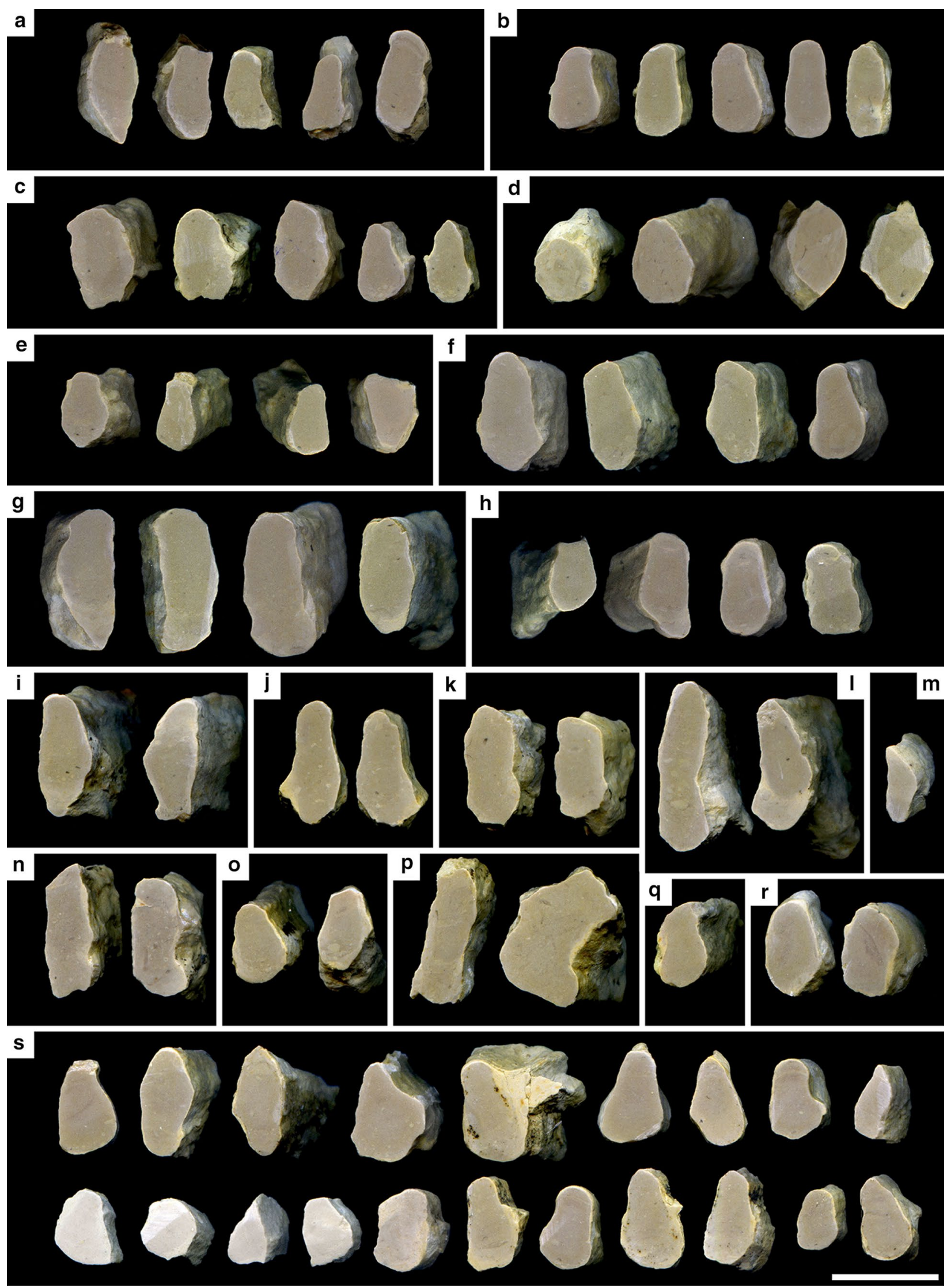
4Fig. 11 Variation in cross section of Oravaichnium carinatum isp. nov. from the Lower Gogolin Beds, Poland. Scale bar $=1 \mathrm{~cm}$. a-r Paratypes, Milowice, INGUJ214P/Mil1 to Mil18, respectively. s Żyglin

ranging from 0.26 to 2.25 (Fig. 13, Table 1). The observed burrow fragments are 50-100 $\mathrm{mm}$ long.

Remarks. Occasionally visible backfill with sediment pads indicates active fill, and chevron-like patterns (Figs. 9a-f, $14 \mathrm{a}-\mathrm{c})$ correspond to features known from the ichnogenus Protovirgularia, which in many cases is produced by bivalves (e.g., Seilacher and Seilacher 1994). O. carinatum differs from $O$. hrabei by its carinate cross section (Table 1). Although the general shape of the burrow varies, upwardly tapered, mostly pear-shaped variants dominate (Fig. 11). In comparison, $O$. hrabei is subrectangular in cross section, with a width/height ratio of about 1 . The burrow orientation of $O$. carinatum in the sediment is different, usually oblique to the bedding, instead of horizontal as in the type material of O. hrabei (cf. Plička and Uhrová 1990; Uchman et al. 2011). Nevertheless, Oblongichnus solodukhoi Bel Haouz et al., 2020, which is herein regarded as a synonym of $O$. hrabei, is also variably oriented and even includes steeply inclined burrows similarly to $O$. carinatum isp. nov.

Overall morphology and the shape of the cross section of $O$. carinatum with its upward-decreasing width resembles Protovirgularia triangularis (Macsotay, 1967) and its more deeply sculpted possible senior synonym $P$. pennata (von Eichwald, 1860), which, however, has its keel at the base and is composed of densely arranged striae instead of sporadic ornamentation (Uchman 1998). Beside smooth burrows of $O$. carinatum, faint striae to more pronounced chevron-like patterns may occur, indicating transitional forms between $O$. carinatum, $P$. triangularis and $P$. pennata. $O$. carinatum shows a wide spectrum of morphological variation with a transition field to O. hrabei and Planolites beverleyensis (cf. Plička and Uhrová 1990; Knaust 2007; Uchman et al. 2011).

Occurrence. The Gogolin Beds in Żyglin, Wojkowice, Mikołów, Libiąż-Moczydło, Żelatowa, Płaza, Wygiełzów, Jaworek, Centawa, Pogorzyce, Strzelce Opolskie and the Terebratula Beds in Górażdże and Strzelce Opolskie. $O$. carinatum occurs in great abundance in the Lower Muschelkalk of Poland and Germany, where this trace fossil forms a characteristic ichnofabric (Stachacz and Matysik 2020).

Ichnogenus Lockeia James, 1879

Lockeia siliquaria James, 1879

Figure 16a
Material. Two catalogued slabs containing several specimens (INGUJ214P/SO4, Gr10), additional specimens observed in the field.

Description. Hypichnial convex semirelief forming small, distinct, asymmetrical, mound-shaped short ridges. The shape of the mounds resembles that of small, almond-shaped bivalve shells, and is steeper on one side than the other. The mounds are, 5-7 mm wide, 7-15 $\mathrm{mm}$ long and up to $10 \mathrm{~mm}$ high. Some specimens occur at the termination of Oravaichnium carinatum isp. nov.

Remarks. Stout forms of Lockeia have been ascribed to $L$. amygdaloides (Seilacher, 1953), and narrow forms to $L$. siliquaria James, 1879. However, Seilacher and Seilacher (1994) and Schlirf et al. (2001) regarded L. amygdaloides as morphological variants of $L$. siliquaria, because they occur in the same beds together with transitional forms between these two ichnospecies. L. siliquaria is the resting trace produced by bivalves in various environments, mostly shallowmarine settings (Seilacher and Seilacher 1994).

Occurrence. Gogolin Beds in Żyglin, Żelatowa, and Terebratula Beds in Strzelce Opolskie.

\section{Lockeia cf. siliquaria}

Figures 17a, 18a, b

Material. Four catalogued slabs with several specimens (INGUJ214P/Ze10 to Ze14), numerous specimens observed in the field.

Description. Hypichnial convex semirelief forming elongate, obtuse-triangular mounds or asymmetrical ridges, 20-50 $\mathrm{mm}$ long, $10-18 \mathrm{~mm}$ wide and up to $20 \mathrm{~mm}$ high. The shape of the mounds resembles that of triangular bivalve shells, and one side is much steeper than the other. Some specimens plunge into the bed or form long, continuous ridges.

Remarks. The specimens described here as Lockeia cf. siliquaria are much larger and more elongate than the small form of L. siliquaria as described above. The shape of this resting trace corresponds to the shape of the bivalve genus Hoernesia, which occurs in great abundance within the same interval.

Occurrence. Terebratula Beds in Górażdże and Strzelce Opolskie. 

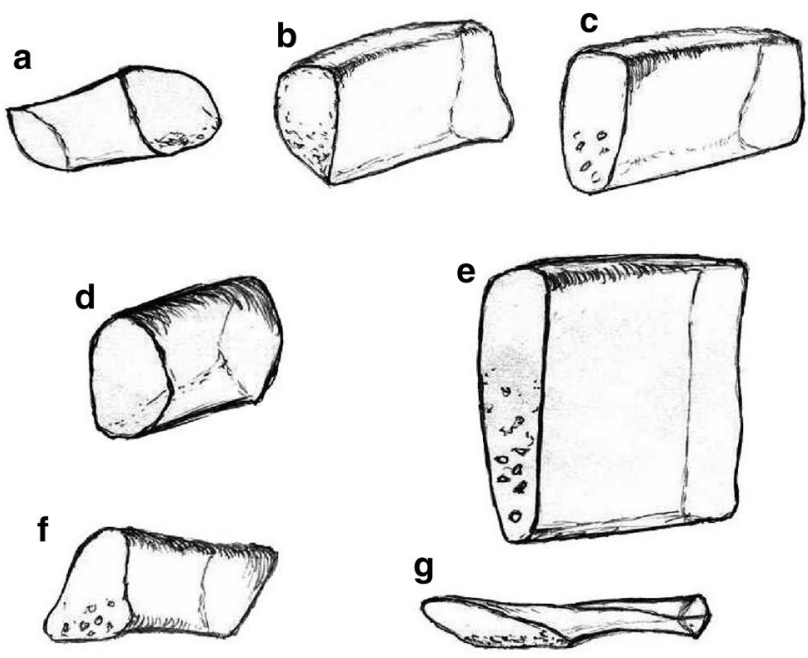

Fig. 12 a-g Sketch of variation of cross section of Oravaichnium carinatum isp. nov. and its transitions to $O$. hrabei, Middle Triassic (Lower Gogolin and Terebratula Beds) of Southern Poland. Scale bar $=1 \mathrm{~cm}$

Ichnogenus Protovirgularia M`Coy, 1850

\section{Protovirgularia dichotoma $\mathrm{M}$ ‘Coy, 1850}

Figure 17

Material. Two catalogued slabs containing at least 14 specimens (INGUJ214P/Ze10,11), more specimens were observed in the field.

Description. Hypichnial convex semirelief or full relief, curved, meandering or winding ribbon or crest, up to $40 \mathrm{~mm}$ long, composed of continuous series of U- or V-shaped pads that form a chevron-like pattern. The burrow is subquadrate or carinate in cross section. The distinct chevron-like pattern locally disappears, in which case only irregular wrinkles are visible or the surface is smooth (Fig. 17b). The pads are $3-15 \mathrm{~mm}$ wide and their width in individual burrows is constant.

Remarks. Some specimens show smooth portions (Fig. 17b) typical of Oravaichnium hrabei and represent intermediate forms between both ichnospecies. Other specimens show features typical of both Lockeia siliquaria and P. dichotoma (Fig. 17a) and represent transitional forms between these ichnospecies. Claus (1965) reported dichotomous trails from the Upper Muschelkalk of Thuringia, Germany, and tentatively attributed them to Protovirgularia. Based on their dichotomous morphology, this trace fossil can be included in P. dichotoma (see Han and Pickerill 1994). P. dichotoma also occurs as burrows and trails in the Lower
Muschelkalk of Berlin-Rüdersdorf (Fig. 17c-f) and Thuringia (Knaust 2007), as well as in the sandy facies at the basin margin in the Trier area (Knaust and Hagdorn 2020). Smooth burrows from the Polish Muschelkalk have usually been assigned to Planolites or Palaeophycus by earlier authors (e.g., Szulc 2000: fig. 22B, C; Kowal-Linka and Bodzioch 2010: fig. 3B; Chrzastek 2013: pl. 3). Because a chevron-like pattern is diagnostic for Protovirgularia (e.g., Uchman 1998), completely smooth specimens (without ornamentation) are herein assigned to Oravaichnium carinatum or O. hrabei. Although Protovirgularia is commonly interpreted as bivalve trace based on experimental ichnology, it can also be produced by polychaetes as assumed in the older literature and proven by preserved remains of their producers in the Upper Muschelkalk of Germany (Knaust 2021b).

Occurrence. Upper Gogolin Beds, Żelatowa quarry; Lower Muschelkalk, Berlin-Rüdersdorf; Upper Muschelkalk, Thuringia.

Ichnogenus Ptychoplasma Fenton and Fenton, 1937

Ptychoplasma cf. excelsum Fenton and Fenton, 1937 Figure $18 \mathrm{c}, \mathrm{d}$

Material. Two catalogued specimens (INGUJ214P/Zy8, Ze8), several specimens observed in the field.

Description. Hypichnial convex full-relief or semirelief, straight or winding discontinuous ridges composed of fusiform to amygdaloid mounds, partly connected in their upper part (usually within the bed) and then forming a serrated wall (Fig. 18c). The mounds are conical or indistinctly carinate in cross section, smooth, 12-30 mm long, 5-15 mm wide, $10-25 \mathrm{~mm}$ high and separated by $10-20 \mathrm{~mm}$.

Remarks. Specimens described here as Ptychoplasma cf. excelsum range in mound size and shape, and although mostly conformable with $P$. excelsum Fenton and Fenton, 1937, other elements known from $P$. conica Pieńkowski and Uchman (2009) and P. vagans (Książkiewicz, 1977) occur as well. High lability of morphology, even within the same burrow, is common.

Occurrence. Gogolin Beds in Żyglin, Żelatowa and Płaza.

\section{Discussion}

The trace fossils described, particularly the ichnogenus Oravaichnium, commonly occur within strata that also contain numerous bivalve shells, some of which occur at the 


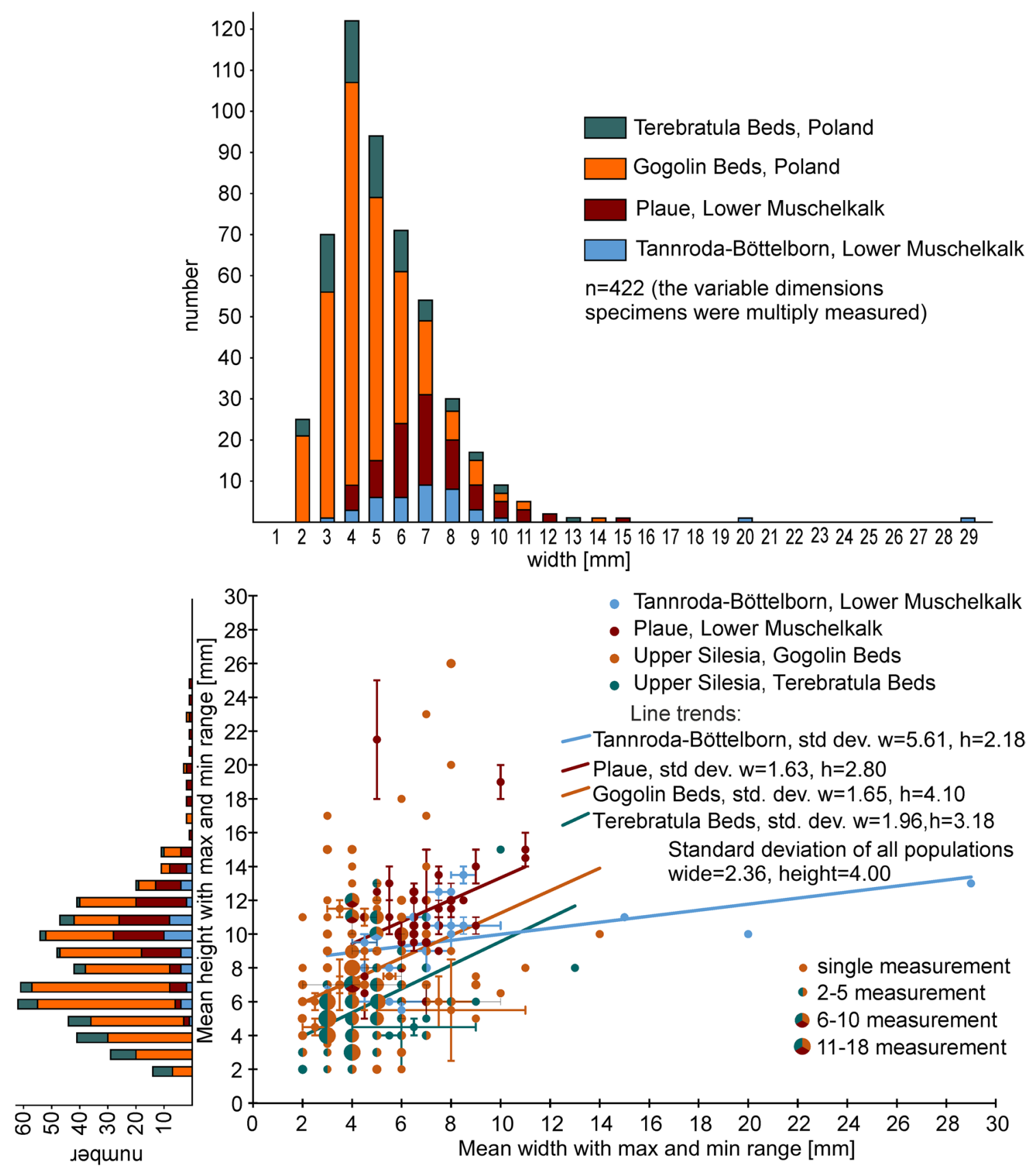

Fig. 13 Plot with width to height ratio of measured specimens

terminations of the burrows and likely represent their trace makers preserved in situ (Fig. 15). Oravaichnium occurs in great abundance in the Lower Muschelkalk, where it forms a characteristic Oravaichnium ichnofabric (Stachacz and Matysik 2020). Equally common in these strata are skeletal fossils of vagile benthos, mainly bivalves, but also gastropods and brachiopods, which are isolated or concentrated in coquinas. Apparently, numerous soft-bodied organisms, for instance burrowing polychaetes, were also present in the Middle Triassic and were probably responsible for making different burrows such as Rhizocorallium, Balanoglossites, Sulcolithos and partly Protovirgularia (e.g. Knaust 2008, 2013, 2021a, b; Knaust and Hagdorn 2020; Stachacz and Matysik 2020). Although rather exceptional than common, bivalve shells preserved within Oravaichnium support the bivalve-related nature of these burrows. Some findings suggest ? Myoconcha bicostata or Pleuromya rugosa and Nuculidae as the trace makers of $O$. carinatum (Fig. 15).

Most of the bivalves, mainly represented by taxa with a wedge foot, are suspension feeders (e.g., Seilacher and 

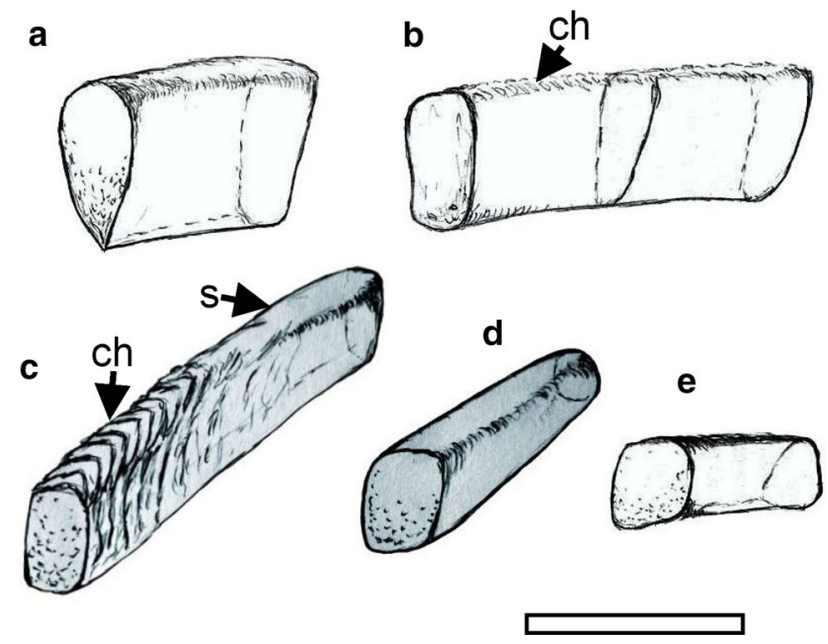

Fig. 14 Sketch of variation of Middle Triassic Oravaichnium carinatum isp. nov. and transitions to similar ichnospecies. Scale bar $=1 \mathrm{~cm}$. a-c Specimens corresponding to Protovirgularia dichotoma, Middle Triassic, ch-chevrons, s-smooth; Upper Gogolin Beds, Żelatowa quarry. d, e Deformed and slightly rounded $O$. hrabei resembling Planolites beverleyensis, Terebratula Beds, Górażdże

Seilacher 1994) and penetrate the sediment only slightly, due to anchoring and moving over the surface using their wedge-like foot. Predepositional forms of $O$. hrabei known from Palaeogene deep-sea flysch deposits of the Outer Carpathians probably represent this type of behaviour (Uchman et al. 2011). Such trace fossils have been reported from the Cenozoic in a few localities (Buatois et al. 2017). In fact, $O$. carinatum is very common and abundant in the Muschelkalk but has not yet been properly described in the literature.

Mass occurrences of $O$. carinatum and rare $O$. hrabei in the Polish and German Muschelkalk suggest a different mode of formation of these burrows and slightly different behaviour of their trace makers. Some relatively deep and densely arranged exichnial Oravaichnium (Figs. 6a, b, 7c, d, 8a-d) seem to be a product of deposit-feeding bivalves searching for food. Moreover, some burrows show distinct faecal pellets within their fill, which resulted from bivalve feeding activity (Fig. 11a-c, j, o). These burrows were most likely produced by small, quite mobile, deposit-feeding protobranch bivalves such as Nuculacea and Tellinacea (Bromley 1996; summarised by López Cabrera et al. 2019). Such trace makers are partly confirmed by relatively rare finds of the bivalve shells, possible Nucula sp., associated with Oravaichnium and Protovirgularia in the Muschelkalk (Fig. 15a, c, d). For comparison, Protovirgularia from different deepsea flysch deposits of Palaeogene age in Japan also co-occur with protobranch bivalve skeletal fossils, mostly Acila, Portlandia and Nucula (Nara and Ikari 2011, and references therein). Among the best indications for the origin of many Protovirgularia by protobranch bivalves are neoichnological experiments performed by Seilacher and Seilacher (1994).
Transitions between Protovirgularia and Oravaichnium (Fig. 17b) suggest a common trace maker for these two ichnotaxa. The different development (i.e., Protovirgularia, Oravaichnium) depends on many factors, both intrinsic (e.g., biology of the animal) and extrinsic (e.g., deposit type, grain size, water content; Seilacher and Seilacher 1994; Mángano et al. 2002; López Cabrera et al. 2019). According to Mángano et al. (2002) and López Cabrera et al. (2019), the final shape of the burrow is formed by extrinsic factors, mostly substrate. Such relationships have a great control on the formation of Protovirgularia and Oravaichnium, which differ by the presence or absence of a chevron-like pattern, respectively.

The mode of formation of bivalve-produced Protovirgularia burrows is by pushing of the bivalve's foot into the sediment, anchoring, and subsequently pulling the shell with the foot (push and pull mechanism, Trueman 1966; Buatois and Mángano 2011). In cleft-footed bivalves, during anchoring and pulling of the shell, the foot forms a double anchor and leaves a chevron-like pattern in stiff sediment (Seilacher and Seilacher 1994; López Cabrera et al. 2019). The burrows showing this pattern are typical of cleft-foot molluscs, represented by primitive Protobranchia and Arcacea, as well as scaphopods (Seilacher and Seilacher 1994). In contrast, other, more evolutionary advanced, wedge-foot bivalves usually produce different smooth and regular burrows, or traces composed of series of knobs or mounds as in Ptychoplasma (e.g., Uchman et al. 2011). The formation of smooth trails and burrows by the modern freshwater bivalve Unio was also observed by one of the authors in sandy substrate of clear water of Biała Nida and Kacanka rivers, central Poland (MS, personal observations, May 2020). The difference between traces produced by these two groups of bivalves resulted directly from the differences in their foot anatomy. However, intermediates between smooth and chevroned burrows (Oravaichnium-Protovirgularia transition field, Figs. 9a-f, $13 \mathrm{a}-\mathrm{c})$ are present in the Muschelkalk and show that they were produced by the same kind of organism.

The final shape of the burrow (i.e. presence or absence of chevrons) is also caused by substrate characteristics and not only the bivalve trace maker's anatomy. Most ichnological studies of bivalve activities in the fossil record (e.g., Plička and Uhrová 1990; Mángano et al. 2002; Uchman et al. 2011; López Cabrera et al. 2019), as well as neoichnological observations (e.g., Seilacher and Seilacher 1994), concern siliciclastic deposits of fine-grained sand, usually in contact with a silty or muddy layer. The burrows formed in such deposits display subtle details of the anchoring bivalve. The bivalve burrows from the Muschelkalk occur almost exclusively in calcareous mud (Stachacz and Matysik 2020) and are represented mostly by smooth Oravaichnium. Such conditions (water-saturated, thixotropic, with a soup-like consistency) possibly caused the domination of smooth burrows 

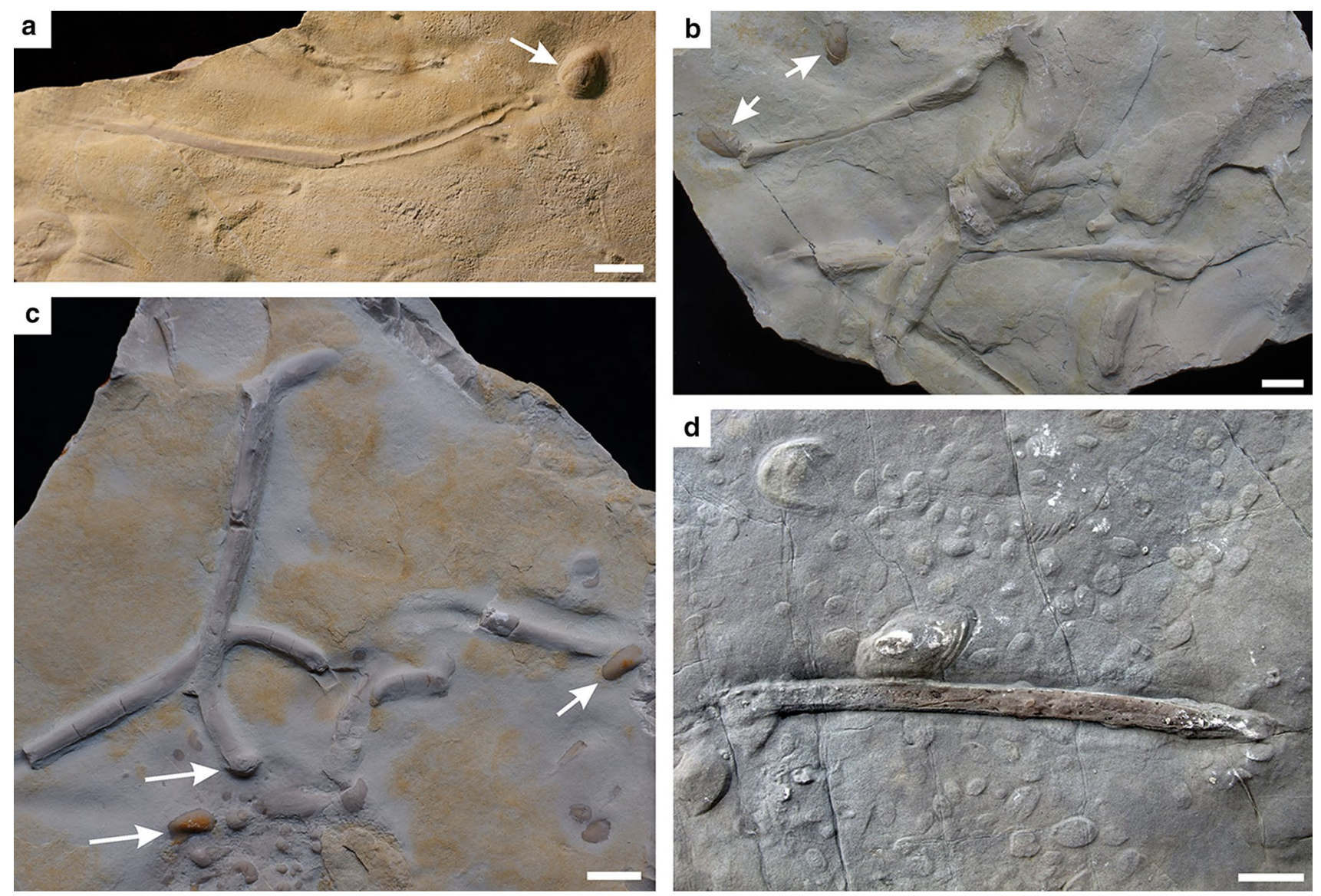

Fig. 15 Oravaichnium associated with bivalve shells and their moulds (arrows). Scale bars $=1 \mathrm{~cm}$. a Upper Gogolin Beds, Żelatowa. b, c Lower Gogolin Beds, Żyglin. d O. hrabei together with casts of

Hoernesia socialis (large) and numerous specimens of Nuculoidea (small). Tannroda-Böttelborn, Lower Muschelkalk (mu3)
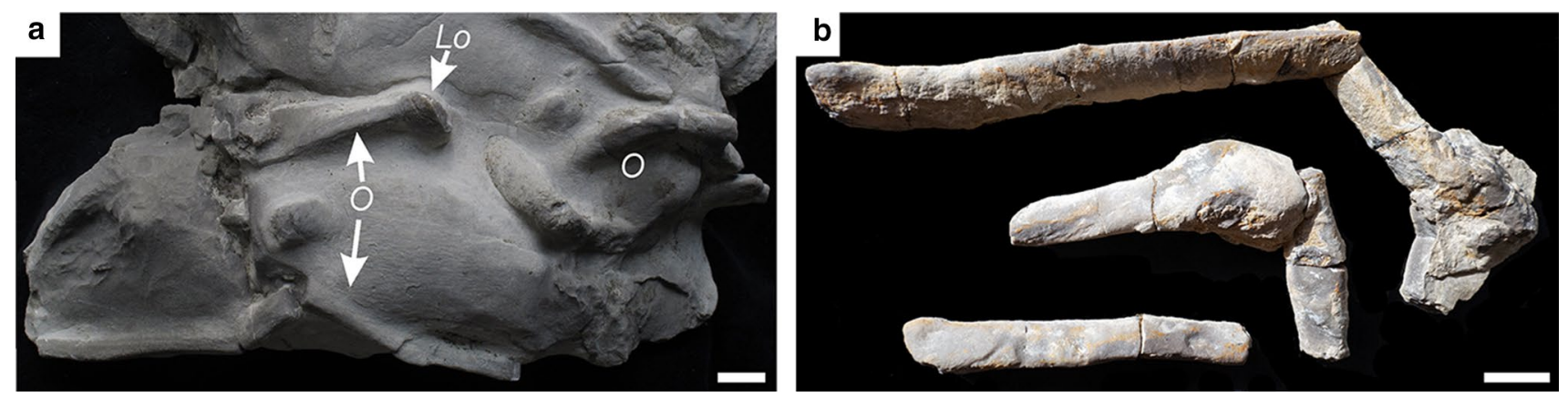

Fig. 16 Burrows with brittle deformation leading to the generation of ichnoclasts. Scale bars $=1 \mathrm{~cm}$. a Upper Gogolin Beds, Strzelce Opolskie, Lockeia siliquaria in the burrow termination (Lo), O-Oravaichnium, INGUJ214P/SO4. b Rittersdorf, Lower Muschelkalk (mu2)

(Oravaichnium), which are usually irregular and deformed (Figs. 10a, 11p), because the bivalve foot could not anchor as efficiently as in sand, causing it to slide. The transitional forms with both smooth and chevroned portions (Oravaichnium-Protovirgularia, Figs. 13a-c, 17a, b) indicate lateral changes in the consistency of the micritic deposit.
The same observation is confirmed by completely smooth polychaete burrows Rhizocorallium commune that in places bear scratch traces (Stachacz and Matysik 2020). Most likely, irregular cohesion of the substrate at different depths was the reason for the formation of Oravaichnium carinatum with variable morphologies, tapered both upward and downward, or completely irregular (Figs. 11, 

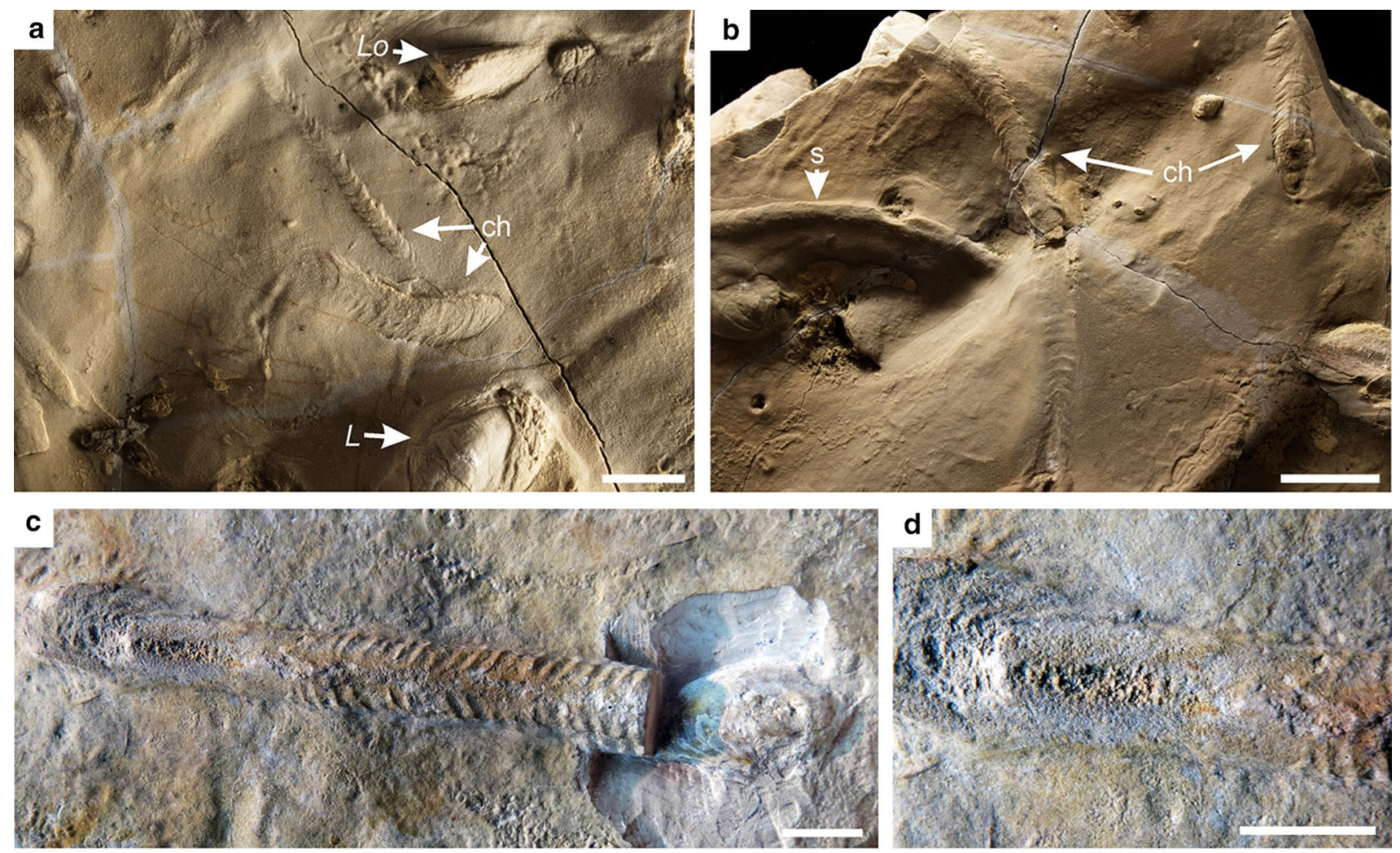

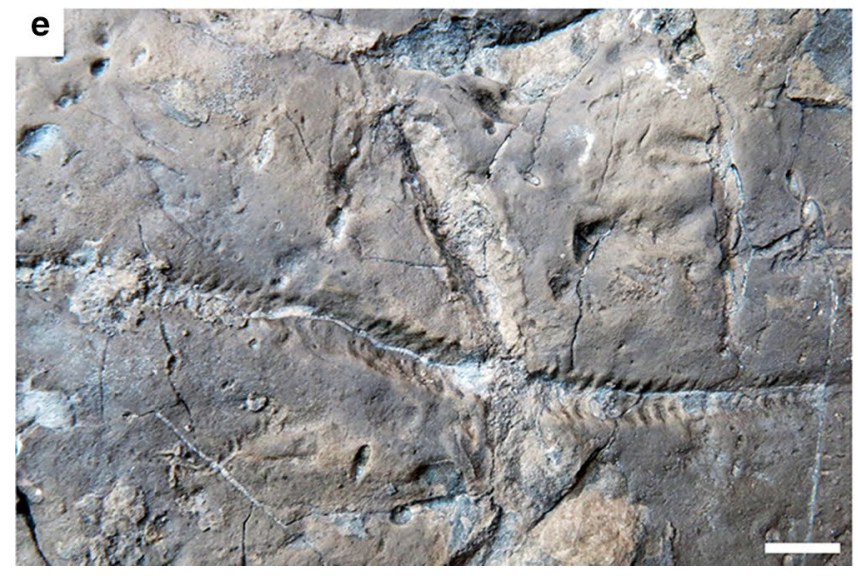

Fig. 17 Protovirgularia dichotoma. Scale bars $=1 \mathrm{~cm}$. a, b Upper Gogolin Beds, Żelatowa, smooth part (s), chevron (ch), and Lockeia (Lo) arrowed (INGUJ214P/Że1, 2). c, d Burrow (hyporelief) with associated bivalve Hoernesia socialis (excavated) and tiny faecal pellets accumulated at the base. Lower Muschelkalk, Berlin-Rüdersdorf

12). However, calcarenite containing Oravaichnium shows only smooth burrows without chevron sculpture (Fig. 10d). The difference in preservational details between burrows in fine-grained siliciclastic deposits (cf. Seilacher and Seilacher 1994; Mángano et al. 2002) and calcarenites of the Muschelkalk results from coarser and poorly sorted carbonate grains (i.e., bioclasts) in the latter case.

O. hrabei from Eocene flysch deposits (Plička and Uhrová 1990; Uchman et al. 2011) and Permian carbonates (Bel

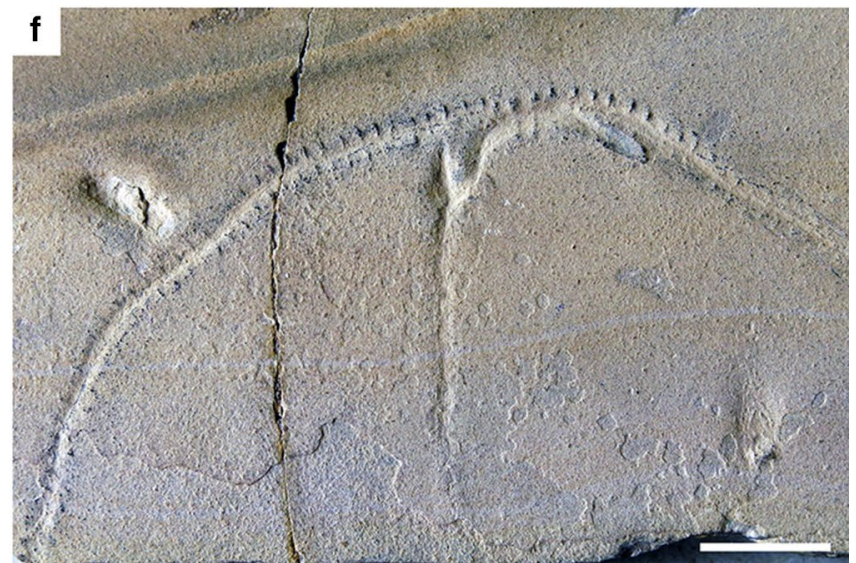

(MB.W.2012). e Firmground surface with trails or shallow burrows (epirelief). Lower Muschelkalk, Berlin-Rüdersdorf (MB.W.1874). f Upper Muschelkalk, Schlotheim (Thuringia). Original specimen from Claus (1965, SMF19520)

Haouz et al. 2020) is more problematic in terms of origin. In both cases, burrows are very regular, undeformed and smooth, but occur in fine-grained sandstone and dolomite, respectively. A possible mode of formation of such burrows in fine-grained sand (which has a greater fossilisation potential for burrow details than carbonate sediment) was also a 'push and pull' mechanism, but the bivalve foot was small and, consequently, the final shape of the burrow was formed 

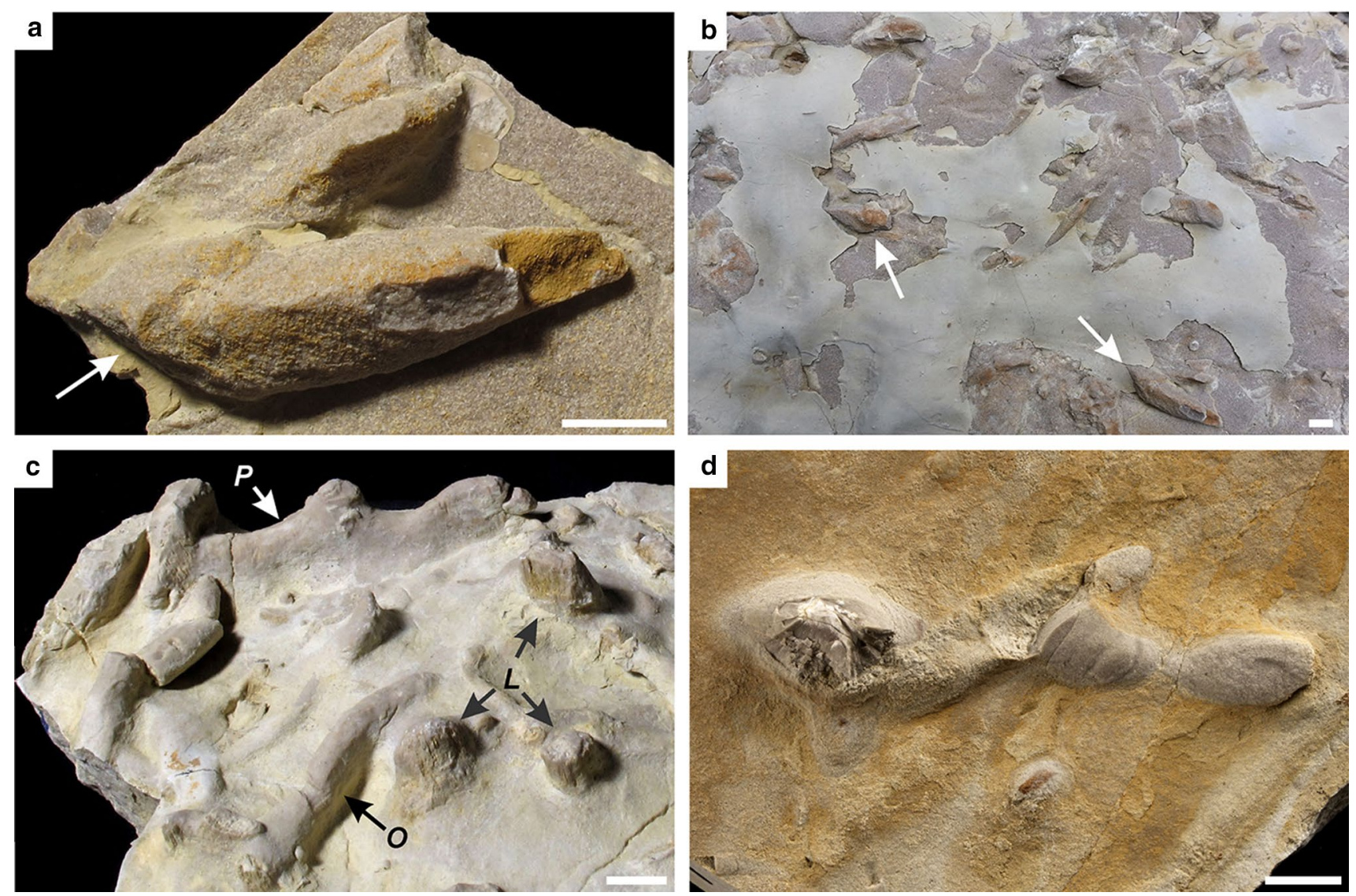

Fig. 18 Lockeia and Ptychoplasma from the Polish Muschelkalk. Scale bars $=1 \mathrm{~cm}$. a, b Lockeia cf. siliquaria (arrows). Żelatowa, Upper Gogolin Beds. c Ptychoplasma cf. excelsum $(P)$, together with

by pulling of the shell and, thus, the chevron pattern was not preserved.

The prevalence of the highly bioturbated 'vermicular limestone' in the Middle Triassic of Poland and Germany, as well as Spain (Mercedes-Martin and Buatois 2021), Italy (Knaust and Costamagna 2012), and Jordan (DK personal observation) suggests that $O$. carinatum and possible other ichnospecies of Oravaichnium are common and that bivalves have a great contribution in relatively deep penetration of sediment. Due to their similarity with other burrows, some of these trace fossils have previously been attributed to other ichnotaxa, especially Planolites (cf. Plička and Uhrová 1990) and Palaeophycus (cf. Bel Haouz et al. 2020).

Burrowing activity of bivalves, although known since the early Cambrian, has rarely had such a large contribution in the bioturbation of deposits as in the Middle Triassic. Likewise, the deep burrowing and abundance of Oravaichnium ichnofabric produced by bivalves, together with the associated Rhizocorallium and Balanoglossites ichnofabrics, represent one of the oldest and most diversified ichnoassociations since the Permian-Triassic mass extinction (Stachacz and Matysik 2020). It seems to be one of the most important
Lockeia isp. (L) and Oravaichnium carinatum $(O)$, Lower Gogolin Beds, Żyglin. d Ptychoplasma cf. excelsum, Upper Gogolin Beds, Żelatowa

steps in deep infaunalisation after the Proterozoic-Palaeozoic boundary, the Cambrian Radiation and the Great Ordovician Biodiversification Event, when the amount of bioturbation significantly increased. In contrast to the first three steps in infaunalisation, when mostly soft-bodied organisms were responsible for deep burrowing (Sepkoski 1979; Droser and Bottjer 1989; Vannier et al. 2010; Mángano and Buatois 2011), bivalves, which were previously insignificant, played a major role in the Middle Triassic infaunalisation.

\section{Conclusions}

1. A lectotype of Oravaichnium hrabei Plička and Uhrová, 1990 has been defined.

2. Oravaichnium carinatum is described and interpreted as a new ichnospecies attributed to the activity of bivalves.

3. Bivalve burrows are much more common than previously believed in the Muschelkalk, and probably worldwide, and include repichnia, fodinichnia, and cubichnia. 
4. Bivalves participated greatly as bioturbators in the Triassic.

5. The Middle Triassic infaunalisation is one of the most important steps in the evolution of Phanerozoic ichnocoenoses.

\begin{abstract}
Acknowledgements This research was financed by the National Science Centre, Poland through Sonata grant 'Trace fossils as a tool for complex palaeoenvironmental analysis: an example from the Middle Triassic (Röt and Muschelkalk) marine carbonates of the KrakówSilesia Upland, Poland' (UMO-2016/21/D/ST10/00748). We would like to thank Bartłomiej Kajdas (CEP UJ) for the access to specimens housed in the museum in Kraków, and Waldemar Obcowski (ING UJ) for preparation of 3-D scans of the trace fossils. We are grateful to Radek Mikuláš (Institute of Geology, Czech Academy of Sciences, Prague, Czech Republic), Andrew Rindsberg (University of West Alabama, Livingston, Alabama, USA), and Mike Reich (PalZ Editor in Chief, Munich) for providing constructive reviews.
\end{abstract}

Open Access This article is licensed under a Creative Commons Attribution 4.0 International License, which permits use, sharing, adaptation, distribution and reproduction in any medium or format, as long as you give appropriate credit to the original author(s) and the source, provide a link to the Creative Commons licence, and indicate if changes were made. The images or other third party material in this article are included in the article's Creative Commons licence, unless indicated otherwise in a credit line to the material. If material is not included in the article's Creative Commons licence and your intended use is not permitted by statutory regulation or exceeds the permitted use, you will need to obtain permission directly from the copyright holder. To view a copy of this licence, visit http://creativecommons.org/licenses/by/4.0/.

\section{References}

Assmann, P. 1944. Die Stratigraphie der oberschlesischen Trias. Teil II - Der Muschelkalk. Abhandlungen des Reichsamts für Bodenforschung 208: 1-124.

Bachmann, G.H., and H.W. Kozur. 2004. The Germanic Triassic: correlations with the international chronostratigraphic scale, numerical ages and Milankovitch cyclicity. Hallesches Jahrbuch für Geowissenschaften B26: 17-62.

Batsch, A.J.G.C. 1802. Taschenbuch für mineralogische Excursionen in die umliegende Gegend um Jena, 1-361. Weimar: Verlag des Industrie-Comptoirs.

Bel Haouz, W., A. Lagnaoui, and V.V. Silantiev. 2020. A new possible bivalve burrow Oblongichnus solodukhoi from the late Kazanian (middle Permian) stratotype section in Russia. Palaeoworld 29: 96-107.

Bromley, R.G. 1996. Trace fossils, biology, taphonomy and applications, 2nd ed., 1-361. London: Chapman and Hall.

Bromley, R.G., A. Uchman, M.R. Gregory, and A.J. Martin. 2003. Hillichnus lobosensis igen. et isp. nov., a complex trace fossil produced by tellinacean bivalves, Paleocene, Monterey, California, USA. Palaeogeography, Palaeoclimatology, Palaeoecology 192: 157-187.

Buatois, L.A., and M.G. Mángano. 2011. Ichnology: organism-substrate interactions in space and time, $1-358$. New York: Cambridge University Press.
Buatois, L.A., M. Wisshak, M.A. Wilson, and M.G. Mángano. 2017. Categories of architectural designs in trace fossils: a measure of ichnodisparity. Earth-Science Reviews 164: 102-181.

Chrząstek, A. 2013. Trace fossils from the Lower Muschelkalk of Raciborowice Górne (North Sudetic Synclinorium, SW Poland) and their palaeoenvironmental interpretation. Acta Geologica Polonica 63: 315-353.

Claus, H. 1965. Eine merkwürdige Lebensspur (Protovirgularia? sp.) aus dem Oberen Muschelkalk NW-Thüringens. Senckenbergiana Lethaea 46: 187-191.

Deutsche Stratigraphische Kommission, eds. (coord. H. Hagdorn, and T. Simon for the "Subkommission Perm-Trias"). 2020. Stratigraphie von Deutschland XIII. Muschelkalk. Teil 1 und 2. Schriftenreihe der Deutschen Gesellschaft für Geowissenschaften 91: $1-1256$.

Droser, M.L., and D.J. Bottjer. 1989. Ordovician increase in extent and depth of bioturbation: implications for understanding early Palaeozoic ecospace utilization. Geology 17: 850-852.

Eichwald, E. von. (d'Eichwald, E.). 1860. Lethaea Rossica ou Paléontologie de la Russie. Décrite et Figurée, Vol. 1. Stuttgart: E. Schweizerbart. (Plates published in 1868).

Fenton, C.L., and M.A. Fenton. 1937. Burrows and trails from Pennsylvanian rocks of Texas. American Midland Naturalist 18: 1079-1084.

Hagdorn, H., and E. Głuchowski. 1993. Palaeobiogeography and stratigraphy of Muschelkalk Echinoderms (Crinoidea, Echinoidea) in Upper Silesia. In Muschelkalk. Schöntaler Symposium 1991, eds. H. Hagdorn, and A. Seilacher, 165-176. Stuttgart: Korb.

Han, Y., and R.K. Pickerill. 1994. Taxonomic reassessment of Protovirgularia $\mathrm{M}^{\text {'Coy }} 1850$ with new examples from the Paleozoic of New Brunswick, eastern Canada. Ichnos 3: 203-212.

Hanken, N.M., R.G. Bromley, and E. Thomsen. 2001. Trace fossils of the bivalve Panopea faujasi, Pliocene, Rhodes, Greece. Ichnos 8: 117-130.

ICZN (International Commission for Zoological Nomenclature). 1999. International Code of Zoological Nomenclature, adopted by the International Union of Biological Sciences, 4th ed., 1-232. London: International Trust for Zoological Nomenclature.

Jaglarz, P., and A. Uchman. 2010. A hypersaline ichnoassemblage from the Middle Triassic carbonate ramp of the Tatricum domain in the Tatra Mountains, southern Poland. Palaeogeography, Palaeoclimatology, Palaeoecology 292: 71-81.

James, U.P. 1879. Description of new species of fossils and remarks on some others, from the Lower and Upper Silurian rocks of Ohio. The Paleontologist 3: 17-24.

Kaim, A., and R. Niedźwiedzki. 1999. Middle Triassic ammonoids from Silesia, Poland. Acta Palaeontologica Polonica 44: 93-115.

Knaust, D. 1998. Trace fossils and ichnofabrics on the Lower Muschelkalk carbonate ramp (Triassic) of Germany: tool for high-resolution sequence stratigraphy. Geologische Rundschau 87: 21-31.

Knaust, D. 2007. Invertebrate trace fossils and ichnodiversity in shallow-marine carbonates of the German Middle Triassic (Muschelkalk). In Sediment-Organisms Interaction: A Multifaceted Ichnology, eds. R.G. Bromley, L.A. Buatois, M.G. Mángano, J.F Genise, and R.N. Melchor. SEPM Special Publication 88: 221-238.

Knaust, D. 2008. Balanoglossites Mägdefrau, 1932 from the Middle Triassic of Germany: part of a complex trace fossil probably produced by burrowing and boring polychaetes. Paläontologische Zeitschrift 82: 347-372.

Knaust, D. 2013. The ichnogenus Rhizocorallium: Classification, trace makers, palaeoenvironments and evolution. Earth Science Reviews 126: 1-47.

Knaust, D. 2021a. Balanoglossites-burrowed firmgrounds - The most common ichnofabric on earth? Earth-Science Reviews 220: 103747. 
Knaust, D. 2021b. A microbialite with its entombed benthic community from the Middle Triassic (Anisian-Ladinian) Muschelkalk Group of Germany. Palaeontographica (A) 320: 1-63.

Knaust, D., and L.G. Costamagna. 2012. Ichnology and sedimentology of the Triassic carbonates of north-west Sardinia, Italy. Sedimentology 59: 1190-1207.

Knaust, D., and H. Hagdorn. 2020. Ichnofauna of the Muschelkalk Group. In Stratigraphie von Deutschland XIII. Muschelkalk, ed. Deutsche Stratigraphische Kommission. Schriftenreihe der Deutschen Gesellschaft für Geowissenschaften 91: 215-225.

Kotański, Z. 1994. Middle Triassic Dasycladaceae of the Upper Silesian-Cracow region and their stratigraphical and palaeoecological significance. In Third International Meeting of Peri-Tethyan Epicratonic Basins. Excursion Guidebook, Cracow 59-66. Warsaw: Polish Geological Institute.

Kowal-Linka, M., and A. Bodzioch. 2010. Sedimentological implications of an unusual form of the trace fossils Rhizocorallium from the Lower Muschelkalk (Middle Triassic) S. Poland. Facies 57: 695-703.

Książkiewicz, M. 1977. Trace fossils in the flysch of the Polish Carpathians. Palaeontologia Polonica 36: 1-208.

López Cabrera, M.I., G.M. Mángano, L.A. Buatois, E.B. Olivero, and C.G. Maples. 2019. Bivalves on the move: the interplay of extrinsic and intrinsic factors on the morphology of the trace fossil Protovirgularia. Palaios 34: 349-363.

M'Coy, F. 1850. On some genera and species of Silurian Radiata in the collection of the University of Cambridge. Annals and Magazine of Natural History (Series 2) 6: 270-290.

Macsotay, O. 1967. Huellas problemáticas y su valor paleoecológico en Venezuela. Geos 16: 7-79.

Mángano, M.G., and L.A. Buatois. 2011. Timing of infaunalization in shallow-marine Early Paleozoic communities in Gondwanan settings: discriminating evolutionary and paleogeographic controls. Palaeontologia Electronica 14(9A): 21.

Mángano, M.G., L.A. Buatois, R. West, and C.G. Maples. 2002. Ichnology of a Pennsylvanian equatorial tidal flat - the Stull Shale Member at Waverly, eastern Kansas. Kansas Geological Survey, Bulletin 245: 1-106.

Matysik, M. 2010. Reefal environments and sedimentary processes of the Anisian Karchowice Beds in Upper Silesia, southern Poland. Annales Societatis Geologorum Poloniae 80: 123-145.

Matysik, M. 2014. Sedimentology of the 'ore-bearing dolomite' of the Kraków-Silesia region (Middle Triassic, southern Poland). Annales Societatis Geologorum Poloniae 84: 81-112.

Matysik, M. 2016. Facies types and depositional environments of a morphologically diverse carbonate platform: a case study from the Muschelkalk (Middle Triassic) of Upper Silesia, southern Poland. Annales Societatis Geologorum Poloniae 86: 119-164.

Matysik, M. 2019. High-frequency depositional cycles in the Muschelkalk (Middle Triassic) of southern Poland: origin and implications for Germanic Basin astrochronological scales. Sedimentary Geology 383: 159-180.

Matysik, M., and J. Szulc. 2019. Shallow-marine carbonate sedimentation in a tectonically mobile basin, the Muschelkalk (Middle Triassic) of Upper Silesia (southern Poland). Marine and Petroleum Geology 107: 99-115.

Mayer, G. 1954. Neue Beobachtungen an Lebensspuren aus dem Unteren Hauptmuschelkalk (Trochitenkalk) von Wiesloch. Neues Jahrbuch für Geologie und Paläontologie, Abhandlungen 99: 223-229.

Mercedes-Martin, R., and L.A. Buatois. 2021. Microbialites and trace fossils from a Middle Triassic restricted carbonate ramp in the Catalan Basin, Spain: evaluating environmental and evolutionary controls in an epicontinental setting. Lethaia 54: 4-25.

Müller, A.H. 1959. Weitere Beiträge zur Ichnologie, Stratinomie und Ökologie der germanischen Trias. Geologie 8: 239-261.
Nara, M., and Y. Ikari. 2011. 'Deep-sea bivalvian highways': An ethological interpretation of branched Protovirgularia of the Paleogene Muroto-Hanto Group, southwestern Japan. Palaeogeography, Palaeoclimatology, Palaeoecology 305: 250-255.

Narkiewicz, K., and J. Szulc. 2004. Controls on migration of conodont fauna in peripheral oceanic areas. An example from the Middle Triassic of the northern Peri-Tethys. Geobios 37: 425-436.

Nawrocki, J., and J. Szulc. 2000. The Middle Triassic magnetostratigraphy from the Peri-Tethys Basin in Poland. Earth and Planetary Science Letters 182: 77-92.

Orłowski, S., and A. Żylińska. 2002. Lower Cambrian trace fossils from the Holy Cross Mountains, Poland. Geological Quarterly 46: 135-146.

Pervesler, P., and M. Zuschin. 2004. Lucinoid bivalve trace fossil Saronichnus abeli igen. et isp. nov. from the Miocene molasse deposits of Lower Austria, and its environmental significance. Geologica Carpathica 55: 11-115.

Pieńkowski, G., and A. Uchman. 2009. Ptychoplasma conica isp. nov. - a new bivalve locomotion trace fossil from the Lower Jurassic (Hettangian) alluvial sediments of Sołtyków, Holy Cross Mountains, Poland. Geological Quarterly 53: 397-406.

Plička, M., and J. Uhrová. 1990. New trace fossils from the Outer Carpathians flysch (Czechoslovakia). Acta Musei Moraviae, Scientiae Naturales 75: 53-59.

Richter, R. 1850. Aus der thüringischen Grauwacke. Zeitschrift der Deutschen Geologischen Gesellschaft 2: 198-206.

Rindsberg, A.K., and A.J. Martin. 2003. Arthrophycus in the Silurian of Alabama (USA) and the problem of compound trace fossils. Palaeogeography, Palaeoclimatology, Palaeoecology 192: 187-219.

Schäfer, W. 1962. Aktuo-Paläontologie nach Studien in der Nordsee, 1-666. Frankfurt: Kramer.

Schlirf, M., A. Uchman, and M. Kümmel. 2001. Upper Triassic (Keuper) non-marine trace fossils from the Haßberge area (Franconia, south eastern Germany). Paläontologische Zeitschrift 75: 71-96.

Schütte, J.H. 1761. Oryctographia Jenensis, sive fossilium et mineralium in agro Jenensi, 1-141. Jena: Güthuius.

Seilacher, A. 1953. Studien zur Palichnologie II. Die fossilen Ruhespuren (Cubichnia). Neues Jahrbuch für Geologie und Paläontologie, Abhandlungen 98: 87-124.

Seilacher, A. 1955. Spuren und Fazies im Unterkambrium. In Beiträge zur Kenntnis des Kambriums in der Salt Range (Pakistan), eds. O.H. Schindewolf, and A. Seilacher. Abhandlungen der Akademie der Wissenschaften und der Literatur zu Mainz (Mathematischnaturwissenschaftliche Klasse) 1955: 373-399.

Seilacher, A. 1990. Aberrations in bivalve evolution related to photoand chemosymbiosis. Historical Biology 3: 289-311.

Seilacher, A. 2000. Ordovician and Silurian arthrophycid ichnostratigraphy. In Geological exploration in Murzuq Basin, eds. M.A. Sola and D. Worsley, 237-258. Amsterdam: Elsevier Science BV.

Seilacher, A., and E. Seilacher. 1994. Bivalvian trace fossils: a lesson from actuopaleontology. Courier Forschungsinstitut Senckenberg 169: 5-15.

Sepkoski, J.J. 1979. A kinetic model of Phanerozoic taxonomy diversity. II. Early Phanerozoic families and multiple equilibria. Palaeobiology 5: 222-251.

Stachacz, M., and M. Matysik. 2020. Early Middle Triassic (Anisian) trace fossils, ichnofabrics, and substrate types from the southeastern Germanic Basin (Wellenkalk facies) of Upper Silesia, southern Poland: implications for biotic recovery following the Permian/Triassic mass extinction. Global and Planetary Change 194: 103290.

Stanistreet, I.G., G. Le Blanc Smith, and A.B. Cadle. 1980. Trace fossils as sedimentological and palaeoenvironmental indices in the Ecca Group (Lower Permian) of the Transvaal. Transactions of the Geological Society of South Africa 83: 333-344. 
Szulc, J. 2000. Middle Triassic evolution of the northern peri-Tethys area as influenced by early opening of the Tethys Ocean. Annales Societatis Geologorum Poloniae 70: 1-48.

Trueman, E.R. 1966. Bivalve mollusks: fluid dynamics of burrowing. Science 152: 523.

Uchman, A. 1998. Taxonomy and ethology of flysch trace fossils: revision of the Marian Książkiewicz collection and studies of complementary material. Annales Societatis Geologorum Poloniae 68: 105-218.

Uchman, A., R. Mikuláš, and A.K. Rindsberg. 2011. Mollusc trace fossils Ptychoplasma Fenton and Fenton, 1937 and Oravaichnium Plička and Uhrová, 1990: their type material and ichnospecies. Geobios 44: 387-397.
Vannier, J., I. Calandra, C. Gaillard, and A. Żylińska. 2010. Priapulid worms: pioneer horizontal burrowers at the Precambrian-Cambrian boundary. Geology 38: 711-714.

Zawidzka, K. 1975. Conodont stratigraphy and sedimentary environment of the Muschelkalk in Upper Silesia. Acta Geologica Polonica 25: 217-256. 